\title{
DIMINUTION OF HEAVY METALS IN INDUSTRIAL SOLID WASTE BY AN AMALGAMATION OF MYCO AND VERMI REMEDIATION
}

\author{
$\mathrm{a}^{*}$ Gowthami S., ${ }^{\mathrm{b}}$ Thirumarimurugan M, and 'Sivakumar V. M., \\ $a^{*}$ Research Scholar, Department of Chemical Engineering, Coimbatore Institute of Technology, Tamilnadu, \\ India. Mail id: gowthami.saba91@gmail.com \\ ${ }^{\mathrm{b}}$ Associate Professor, Department of Chemical Engineering, Coimbatore Institute of Technology, Tamilnadu, \\ India. Mail id: thirumarimurugan@gmail.com \\ ${ }^{c}$ Assistant Professor, Department of Chemical Engineering, Coimbatore Institute of Technology, Tamilnadu, \\ India. Mail id: vmsivakumar@gmail.com
}

\begin{abstract}
Due to the development of Industrialization and urbanization, a wide variety of industrial and consumer products, by products and solid waste has been produced. The solid waste generated constitutes the hazardous substance which possesses certain impacts on humans and their environment. In that heavy metal pollution from industries are the serious environmental problems. Rapid development in industries in the last few decades resulted in the strenuous task for finding to manage the waste generated. These hazardous solid wastes have been formulated into reusable end product by the process of bioremediation. Bioremediation is a natural process, which involves the use of organism to remove or neutralize the toxic pollutant from the contamination site. This review focus on the toxic effects of heavy metals on the environment and on the human health as well as the possible bioremediation method of these metals using fungus and earthworm. In order to conserve the environment and resources, the biological remediation by both fungus and earthworm for heavy metals and their efficiency have been summarised in detail.
\end{abstract}

\section{Indexing terms/Keywords}

Solid waste, heavy metals, fungus, earthworm, Bio-fertilizer.

Academic Discipline And Sub-Disciplines

Chemical Engineering; Environmental studies.

\section{TYPE (METHOD/APPROACH)}

Bioremediation; Mycoremediation; Vericomposting.

\section{INTRODUCTION}

The production of solid waste is one of the serious environmental issues in developing countries, which needs special attention. The industrial sectors are the major potential for generation of hazardous waste such as heavy metals, cyanides, pesticides, complex aromatic compounds (such as PCBs) and other toxic chemicals. The Central Pollution Control Board (CPCB) estimated that, hazardous waste generated in the India to be around 6.23 million tones. Out of this, $49.55 \%$ is recyclable, $6.67 \%$ incinerable and remaining $43.78 \%$ is disposable in secured landfills (CPCB, 2009). Twelve states of the country (Maharashtra, Gujarat, Tamil Nadu, Orissa, Madhya Pradesh, Assam, Uttar Pradesh, West Bengal, Kerala, Andhra Pradesh, Karnataka and Rajasthan) account for about $97 \%$ of the total waste generation. Among these hazardous waste, the presence of heavy metals in the solid waste plays a major role in the contamination of the environment. These heavy metals are toxic even at very low concentrations such as arsenic, cadmium, chromium, copper, lead, mercury, nickel, selenium, silver, zinc etc. are carcinogenic and mutagenic in nature (Salem et al., 2000). In that some of the heavy metals are essential for living beings growth and optimum performance. Due to the industrial revolution, the concentration of several heavy metals has been increased in soil and water. They created the alarming situation for human life and aquatic biota. The contaminated water bodies and land need to be rectified to make them free from heavy metals and trace elements, in order to make the environment healthier for human beings. There are numerous techniques to remove these heavy metals, including chemical precipitation, oxidation or reduction, filtration, ion-exchange, reverse osmosis, membrane technology, evaporation and electrochemical treatment. But most of these techniques become ineffective, when the concentrations of heavy metals are less than $100 \mathrm{mg} / \mathrm{L}$ (Ahluwalia and Goyal et al., 2007). Most heavy metal salts are water-soluble and get dissolved in wastewater, so it cannot be separated by physical separation methods (Hussein et al., 2004). When the concentration of heavy metals is very low, which means that utilization of physico chemical methods are very low or ineffective. The treatments technologies convert the waste into immobilize toxic components, or reduce the quantity of the waste. Use of microorganisms for remediation purposes is sustainable remediation technologies to rectify and re-establish the natural condition of heavy metal contaminated environment. The metabolic potential of fungus can be utilized for the reduction of heavy metals in the environment and make hazardous substance into less hazardous form (Asgher et al., 2007; Haritash and kaushik, 2009). Implementation of fungi in the process of remediation is called Mycoremediation. In recent days, microbes like fungus, bacteria and algae have been effectively used as adsorbing agents for removal of heavy metals (Terres et al., 1998; Munoz et al., 2006; Munoz and Guieysse, 2006). The high surface to volume ratio of microorganisms and their capability to detoxify metals are among the reasons that they are considered as potential alternative to synthetic resins for remediation of heavy metal contaminated liquid and solid wastes (Kapoor et al., 1999; Magyarosy et al., 2002). So the fungus can be use for the reduction of heavy metals from solid waste from the industries. Then the treated solid waste will be converted into bio-fertilizer by the process of vermicomposting. Vermicomposting is an aerobic composting process in which certain varieties of earthworms can be used, it have the ability to break down organic materials. Earthworms mechanically break down compostable and partially decomposed materials by eating them, and biochemical decomposition occurs by the use of bacteria and chemicals in the 
worms' digestive system (Rajiv singh and Das, 2005). The use of earthworms in solid waste management has been termed as Vermistabilization (Neuhauser et al., 1988). The various industrial wastes which have been Vermicomposted and converted into nutrient rich manure include paper waste (Elvira et al., 1998, Kaur et al., 2010 ), textile mill sludge (Garg and Kaushik, 2005), guar gum industrial waste (Suthar, 2006), sugar industry wastes (Sen and Chandra, 2007), distillery sludge (Suthar and Singh), leather industry (Ravindran et al., 2008) and beverage industry sludge (Singh et al., 2008), agroindustrial sludge (Suthar, 2010), primary sewage sludge (Hait and Tare, 2011), tannery industries (Ravindran and sekaran, 2011). Earthworm plays an important role in the indication of an ecosystem health and many studies have been found for the response of earthworm to the heavy metals (Ndegwa and Thompson, 2001). Earthworms have the ability to survive in many kinds of chemical contaminants including heavy metal (Nahmani et al., 2007). The reduction of heavy metal by vermicomposting is an enhancement of the natural process, which integrates earthworm and microbes, they play an very important role in accumulating heavy metals in the earthworm tissues. In the process of vermicomposting, it supposes that earthworms are useful to clean up the environment from various pollutants and also heavy metals (Spugeon and Hopkin, 1999a). Different types of composting earthworms such as Eisenia fetida, Perionyx excavates, Eudrilus eugenia , Eisenia Andrei and Lampito mauritii these are the epigeic earthworm used for the heavy metal remediation process (Pereira and Arruda, 2003). In this review some of the efforts to be made to use fungi in the reduction of heavy metals from industrial solid waste and the earthworm to be inoculated in the partially reduced heavy metal contaminated solid waste. The composting worm can be used to reduce the remaining heavy metal concentration and convert the industrial solid waste into nutrient rich bio-fertilizers.

\section{SOURCES OF HEAVY METALS}

Heavy metals occur in the natural environment through the process of both geogenic and anthropogenic. Due to the pedogenetic processes of weathering of parent materials, the heavy metal levels that are regarded as trace $(<1000 \mathrm{mg}$ $\mathrm{kg}-1$ ) and rarely toxic (Kabata-Pendias and Pendias, 2001; Pierzynski et al., 2000).Compare to the process of both pedogenic or lithogenic activity, heavy metals source from anthropogenic activity have more mobility in nature (Kuo et al., 1983; Kaasalainen and Yli-Halla, 2003). The major source of anthropogenic activity include metal mine tailings, disposal of high metal wastes in improperly protected landfills, lead based paints, fertilizer, sewage sludge, compost, pesticides, coal combustion residues, petrochemicals, application of $\mathrm{p}$ fertilizers, disposal of domestic waste materials (Khan et al., 2008; Zhang et al., 2010; Basta et al., 2005).

\subsection{Fertilizers}

The first influence of human to the soil is done by the activity of agriculture (Scragg, 2006). The major source of heavy metals from the fertilizers are $\mathrm{p}$ fertilizer, they especially contain cd. Phosphate compound contains the wide range of heavy metals (Loganathan et al., 2008; Bolan, 2003; Wuana and Okieimen, 2011). Contamination of agricultural soil by cadmium is the sever environmental concern, because it reaches the food chain by the regular use of Cd-containing $P$ fertilizers. The growth of plants not only depend on the macro nutrients $(\mathrm{N}, \mathrm{P}, \mathrm{K}, \mathrm{S}, \mathrm{Ca}$, and $\mathrm{Mg}$ ), they also depend on the micro nutrients. Enormous amount of fertilizers are frequently added to the agricultural field to provide plenty of $\mathrm{N}, \mathrm{P}$, and $\mathrm{K}$ for crop growth. The heavy metals such as $\mathrm{cd}$ and $\mathrm{pb}$ have been presented as impurities in the compound, that providing the elements N, P, K (Jones and Jarvis, 1981).

\subsection{Pesticides}

In recent days, more amount of pesticides are widely used in agriculture and horticulture. But these contains the substantial concentrations of metals. In many formulation of cu containing fungicides such as copper oxychloride and 'Bordeaux' mixture, and as a growth promoter in piggery and poultry units (Bolan et al., 2003; Wightwick et al., 2013). As a result of continuous use of $\mathrm{Cu}$ fungicides leads to the Accumulation of $\mathrm{Cu}$ in agricultural soils (Chopin et al., 2008; Heemsbergen et al., 2010; Hildebrandt et al., 2008; Wightwick et al., 2010). Due to enormous accumulation of Cu in soils, it leads the toxicity to plants and microbial communities, for instance, formation of bare sterile patches in orchards (van Zwieten et al., 2007; Zhou et al., 2011).

\subsection{Metal Mining and Industrial Wastes}

Mining and milling of metal ores coupled with industries have been the backbone of the economy of the many countries, but it leads to the wide distribution of metal contaminants in soil. During mining the waste are directly discharged into natural depressions, including onsite wetlands resulting in elevated heavy metal concentrations (Devolder et al., 2003). Particularly in mining and smelting of $\mathrm{Pb}$ and $\mathrm{Zn}$ have resulted in contamination of soil that poses risk to environment. Waste from various industries such as textile, leather processing, dying, paper manufacturing, petrochemicals from accidental oil spills or utilization of petroleum-based products, pesticides, and pharmaceutical facilities and are highly discharging theirs both heavy metal contaminated effluents and solid waste (Sumner, 2000).

\section{EFFECTS OF HEAVY METALS TO THE ENVIRONMENT}

Heavy metal contamination in soil may create hazards to humans and the environment through: direct ingestion or through contaminated soil, the food chain, drinking of contaminated ground water, phyto toxicity, reduction in land usability for agricultural production causing food insecurity, and land tenure problems. $\mathrm{Pb}$. $\mathrm{Cr}$, as, $\mathrm{Zn}, \mathrm{Cd}, \mathrm{Cu}$ and $\mathrm{Hg}$ are the most common heavy metals in the contaminated sites (USEPA, 1996). These heavy metals have the ability to reduce the crop production due to the risk of bioaccumulation and biomagnifications in the food chain and also in the ground water. The hazardous effects of heavy metals depend significantly on the chemical form and speciation of the metal. Once heavy metals are entered into the soil, heavy metals are adsorbed by initial fast reactions (minutes, hours), followed by slow adsorption process (days, years) and redistributed into different chemical forms with varying bioavailability, mobility, and toxicity (Shiowatana et al., 2001; Buekers, 2007).

\subsection{Lead}

February $2017 \quad$ ww w. cirworld.com 
Lead is a metal belonging to group IV and period 6 of the periodic table with atomic number 82, atomic mass 207.2, density $11.4 \mathrm{~g} \mathrm{~cm}-3$, melting point $327.4 \circ \mathrm{C}$, and boiling point $1725^{\circ} \mathrm{C}$. It is bluish gray metal, usually found as combined with other elements such as sulphur (i.e., $\left.\mathrm{PbS}, \mathrm{PbSO}_{4}\right)$, or oxygen $\left(\mathrm{PbCO}_{3}\right)(\mathrm{USDHHS}, 1999)$. The most common forms of lead that are released into the environment are lonic lead, $\mathrm{Pb}(\mathrm{II})$, lead oxides and hydroxides, and lead metal oxyanion complexes. The most stable forms of lead are $\mathrm{Pb}(\mathrm{II})$ and lead-hydroxy complexes. $\mathrm{Pb}$ accumulates in the body organs (i.e., brain), which may lead to poisoning (plumbism) or even death. The presence of lead causes the affects to gastrointestinal tract, kidneys, and central nervous system. Children exposed to lead are at risk for impaired development, lower IQ, shortened attention span, hyperactivity, and mental deterioration, with children under the age of six being at a more substantial risk. Adults usually experience decreased reaction time, loss of memory, nausea, insomnia, anorexia, and weakness of the joints when exposed to lead (NSC, 2009). Lead is not an essential element and it leads toxic to the living beings. Lead can cause serious injury to the brain, red blood cells, nervous system and kidneys (Baldwin and Marshall, 1999). Depending upon the level and duration of exposure, it causes the wide range of biological effects.

\subsection{Chromium}

Chromium is a first-row $d$-block transition metal of group VI B in the periodic table with the following properties: atomic number 24 , atomic mass 52 , density $7.19 \mathrm{~g} \mathrm{~cm}-3$, melting point $1875 \circ \mathrm{C}$, and boiling point $2665 \circ \mathrm{C}$. Chromium does not occur in elemental form, it can be only available in compound. Electroplating industry, Tanning industry and the disposal of $\mathrm{Cr}$ contamination waste are the major source of $\mathrm{Cr}$ contamination (Smith et al., 1995). The two available form of chromium such as CrIII and Cr VI. Majority of the contaminated sites have the form of Chromium (VI). Chromium(VI) is the more toxic form of chromium and is also more mobile. $\mathrm{Cr}(\mathrm{VI})$ is always toxic to living organisms and has been listed as a priority pollutant and a human carcinogen by the US Environmental Protection Agency. In vivo studies have exposed that $\mathrm{Cr}$ (VI) is approximately 100 times more toxic (Beleza, 2001) and 1000 times more mutagenic than $\mathrm{Cr}$ (III) (Czako-Ver et al., 1999). Soluble and un-adsorbed chromium complexes can leach from soil into groundwater. If the pH of the soil increases the leachability of $\mathrm{Cr}(\mathrm{VI})$ also increases. Most of $\mathrm{Cr}$ released into natural water is particle associated, however, and is ultimately deposited into the sediment (Smith, 1995). The major cause of is allergic dermatitis to humans (Scragg, 2006).

\subsection{Zinc}

Zinc is a transition metal with the following characteristics: period 4, group IIB, atomic number 30 , atomic mass 65.4 , density $7.14 \mathrm{~g} \mathrm{~cm}-3$, melting point $419.5 \circ \mathrm{C}$, and boiling point $906 \circ \mathrm{C}$. About $70 \mathrm{mg} \mathrm{kg}-1$ of zinc can be available in crustal rocks (Davies and Jones, 1988), due to the anthropogenic activity, the concentration of the zinc is rising enormously. The discharge from Industrial sources may cause the concentrations of $\mathrm{Zn}$ in drinking water to reach levels that can cause health problems. Zinc is an essential for human health. But in the above the certain concentration it may increase the acidity of waters. Some fish can accumulate $\mathrm{Zn}$ in their bodies, when they live in $\mathrm{Zn}$-contaminated waterways. Due to the presence of zinc in soil, they can lead contamination to groundwater. Moreover plants also uptake $\mathrm{Zn}$ to their system.

\subsection{Cadmium}

Cadmium is located at the end of the second row of transition elements with atomic number 48, atomic weight 112.4 , density $8.65 \mathrm{~g} \mathrm{~cm}-3$, melting point $320.9 \circ \mathrm{C}$, and boiling point $765^{\circ} \mathrm{C}$. In its compounds, Cd occurs as the divalent $\mathrm{Cd}(\mathrm{II})$ ion. Cadmium is also present as an impurity in several products, including phosphate fertilizers, detergents and refined petroleum products. In addition, acid rain and the resulting acidification of soils and surface waters have increased the geochemical mobility of $\mathrm{Cd}$, and as a result its surface-water concentrations tend to increase as lake water pH decreases (Campbell, 2006). The application of agricultural inputs such as fertilizers, pesticides, and biosolids (sewage sludge), the disposal of industrial wastes or the deposition of contaminants increases the total cadmium concentration in soils, and the bioavailability of this $\mathrm{Cd}$ determines whether plant Cd uptake occurs to a significant degree (Weggler et al., 2004). Cadmium is very biopersistent but has few toxicological properties and, once absorbed by an organism, remains resident for many years. Due to the presence of cadmium, which affects the several enzymes in the body. It is believed that the renal damage that results in proteinuria is the result of $\mathrm{Cd}$ adversely affecting enzymes responsible for reabsorption of proteins in kidney tubules. Cadmium also reduces the activity of delta-aminolevulinic acid synthetase, arylsulfatase, alcohol dehydrogenase, and lipoamide dehydrogenase (Manahan, 2003).

\subsection{Copper}

Copper is a transition metal which belongs to period 4 and group IB of the periodic table with atomic number 29 , atomic weight 63.5 , density $8.96 \mathrm{~g} \mathrm{~cm}-3$, melting point $1083^{\circ} \mathrm{C}$ and boiling point $2595^{\circ} \mathrm{C}$.Copper is a very versatile heavy metal, which can be available in two redox states, $\mathrm{Cu}(\mathrm{II})$ and $\mathrm{Cu}(\mathrm{I})$. In higher concentrations it can cause anaemia, liver and kidney damage, and stomach and intestinal irritation. If the blood copper level is excess of $7.9 \mathrm{mg} / \mathrm{ml}$ have the effects of jaundice, renal dysfunctions, and toxic shock. The contamination of copper in drinking water is due the reason of Cu pipes, as well as additives agents added for the control of algae growth. The tracer metal contamination in soil, may pose both direct and indirect threats: direct, through negative effects of metals on crop growth and yield, and indirect, by entering the human food chain with a potentially negative impact on human health. Even a reduction in yield of crops by a few percent could lead to a significant long-term loss in production and income.

\section{MYCOREMEDIATION AS AN EMERGING TECHNOLOGY}

Mycoremediation is the use of fungus and its processes for the reduction of pollution. The removal of heavy metals pollutant using fungal biomass is easier and cheaper than the conventional or traditional adsorbent techniques using 
activated carbon, coal or ion exchange (Ashida, 1965). The end products from this remediation process are nonhazardous. Fungi are ability to tolerate and detoxify metals by numerous mechanisms including valence transformation, extra and intracellular precipitation and active uptake (Gadd, 1993; Ross, 1975). By means of mechanism produced in direct response to metal species, the organism has been the ability to survive metal toxicity is termed as metal resistance. Biological mechanisms implicated in fungal survival include extracellular precipitation, complexation and cyrstallization, decreased transport or impermeability, transformation of metals, biosorption to cellwall and pigments, efflux, intracellular compartmentation and sequestration (Gadd, 1990; Gadd, 1992; Mehra, 1991; Bai and Abraham 2003). The studies have been conducted to screen the filamentous fungi from metal polluted sites for their diversity, metal tolerance and their biosorption potential. Filamentous fungi are well recognized for their superior capacities to produce a wide variety of extracellular enzymes, organic acids and other metabolites, and for their capabilities to adapt the environmental constraints (Elander and Neway, 1989). The members of Deuteromycetes such as Aspergillus, Penicillium and Trichoderma species are known to produce numerous extracellular enzymes, which are put to good use in biotechnology (Bumpus et al., 1985). Similarly, the Basidiomycetes white rot fungi such as Phanerochaete chrysosporium are significant for their abilities to produce nonspecific ligninases and peroxidases which can be used to degrade pollutants in liquid effluents and in soils (Qazilbash, 2004). The living and dead cell of the fungus have the capacity to eradicate the heavy metals. Fungi are used as an economical and nonstop supplying biomass for removing the metal ions in polluted area (Kapoor and Viraraghavan, 1998). Some of the isolated fungi such as Trichoderma autroviride, T. harzianum, and $T$. virens were found as the good biosorption agent of heavy metal ions (Siddiquee et al., 2013). The selected strains of fungi are potential utilized in the research area due to its presence in high polluted area (Lopez Errasquin and Vazquez, 2003). The study reported that $A$. niger is able to grow on culture plates amended with heavy metals and showed five times enhanced inhibition than the growth of yeast (Prince et al., 2001). The resistance level of different strains of filamentous fungi such as $T$. aureoviride, $T$. harzianum, and $T$. virens are diverse for different concentration of heavy metals. In that the fungal starin T. virens strain $\mathrm{T} 128$ gave the highest tolerance ability for $\mathrm{Ni}_{3+}$ and $\mathrm{Pb}_{2+}$ in a 1200 mg/L concentration (Siddiquee et al., 2013). The maximum removal of heavy metals have been mainly depend on the accumulation and uptake capacity of the strain $T$. harzianum. The starin $T$. virens shoed the highest tolerance and uptake capacity towards the metal zinc. The mycelium of Rhizopus is an excellent biosorbent towards lead, cadmium, copper, zinc and uranium (Volesky, 1994). Mucorales species is found as the excellent biosorbents (Remacle, 1990) and Fusarium flocciferum is used to remove cadmium and nickel from industrial effluents (Delgado et al., 1998). However, the use of fungus in the bioremediation is not only the cleaning process, but also protect the environment and biodiversity as well as allowing for the subsequent reuse (Ashida, 1965; gadd, 1986; Brierley and Beierley, 1993). Fungi have a versatile group, they can able to adapt and grow under varying conditions of $\mathrm{pH}$, temperature and nutrient availability as well as at high metals concentration (Ashida, 1965; Yazdani et al., 2010; Anand et al., 2006). Fungi are one of the most appropriate organisms used for bioremediation. Because, they can abide varies environmental and toxic conditions such as a higher concentration of metals levels, and lower $\mathrm{pH}$ condition also. They have the ability and capacity to bind with heavy metals to their cell walls which are enhanced the intracellular accumulation of those toxins. The ability of selected fungi strains towards remediation of heavy metals ions are evaluated by the bioaccumulations characteristics of the fungus towards the heavy metals. Many researcher found that Phanerochaete chrysosporium ability to grow in both solid and liquid environment to degrade a wide range of xenobiotic effectively D. L. Huang (Huang et al., 2006). Researchers reported that the initial compost have $70.5 \%$ of lead $(\mathrm{pb})$ was bound to the residual fraction in reactor $\mathrm{C}$ (contain spore suspension of white-rot fungus) and $58.7 \%$ of residual fraction of pb in reactor B (not contain spore suspension of white-rot fungus), after 80 days of composting the exchangeable lead content in reactor $\mathrm{C}$ and reactor $\mathrm{B}$ was reduced to $0 \%$ and $2.86 \%$ respectively. Result showed that potential hazards of compost in reactor $\mathrm{C}$ were lower than the Reactor $\mathrm{B}$, which indicates that composting with white rot fungus could control the phytotoxicity of $\mathrm{pb}$ in contaminated solid waste. The white-rot fungi can have the capacity to chelate with pb by the carboxyl, hydroxyl or other active functional groups on cell wall surface (Zeng et al., 2007; Li et al., 2004; Yetis et al., 2000) and white-rot fungi could improve the composting process (Huang et al., 2003). The fungus strains such as Aspergillus and Penicillium have shown potential for metal bioremediation (Izadpanah et al., 2009). The adaptation of fungi exposed to heavy metal ions has been examined to increase the tolerance of fungi (yang et al., 2009). Among the fungus strains researcher concluded that, Penicillium simplicissimum was the most tolerant species and showed high growth, even at high concentration $(8000 \mathrm{ppm})$ of Zinc. The researchers revealed that $\mathrm{P}$. chrysosporium are capable of accumulating metal ions in their cells by intracellular uptake, as many researchers validated, and can also be chelated with metal ions by the carboxyl, hydroxyl or other active functional groups on cell (including the dead cell) wall surface. After 60 days of incubation, the concentration of soluble-exchangeable $\mathrm{Pb}$ in B soil (contaminated soil with inoculums of $P$. chrysosporium) even dropped to $0 \mathrm{mg} \mathrm{kg}-1$, while that in A soil (contaminated soil without inoculums of $P$. chrysosporium) and $\mathrm{C}$ (soil without inoculums of $P$. chrysosporium) soil remained 100.5 and $77.0 \mathrm{mg} \mathrm{kg}-1$, respectively. The result of this study showed the least toxicity of $\mathrm{Pb}$ to living organisms, the least stress from $\mathrm{Pb}$ on environment for the significant reduction of $\mathrm{Pb}$ in $\mathrm{B}$ soil by co-incubating the soil with $P$. chrysosporium and the added straws, compared with those in the control soils. All these results might be because the $\mathrm{Pb}$ ion was absorbed by the mycelia of $P$. chrysosporium and chelated by the humus formed in the incubation process (Baldrian, 2003). Researchers reported that the Fungal strains such as Aspergillus niger, Aspergillus sp., Fusarium sp., and Penicillium sp., were tested for their tolerance against different concentrations of heavy metals $\left(\mathrm{NiSO}_{4}, \mathrm{ZnSO}_{4}\right.$ $\mathrm{CdSO}_{4}, \mathrm{Pd} \mathrm{NO}$ ). The concentrations $(1,5,10,15,20,25,30,35,40 \mathrm{ppm})$ of heavy metals $\left(\mathrm{NiSO}_{4}, \mathrm{ZnSO}_{4}, \mathrm{CdSO}_{4}, \mathrm{Pd}\right.$ $\mathrm{NO}_{3}$ ) were used for the selection of fungi. Moreover fungi have been widely used in bioremediation of industrially polluted soils and waters, specifically in the removal of hydrocarbons and heavy metals (Akhtar and Mohan, 1995; Khan, 2001; Potin et al., 2004). Several researchers have reported the use of Aspergillus niger, Aspergillus sp, Penicillium sp and Fusarium sp to remove heavy metals $\mathrm{Cr}, \mathrm{Zn}, \mathrm{Ni}, \mathrm{Pd}$ and $\mathrm{Cd}$ and checked their tolerance ability to see their tolerance towards $\mathrm{CdSO}_{4}, \mathrm{ZnSO}_{4}, \mathrm{PdSO}_{4}$ and $\mathrm{NiSO}_{4}$ in the Soil (Gadd, 1990; Fourest et al., 1994; Bai and Abraham, 2001; Teskova and Petrov, 2004). Similar study showed that Aspergillus niger was better to grow or tolerance heavy metals as 
compared to other fungi (Price et al., 2001). Result shows that Aspergillus niger and Aspergillus sp., were more tolerant as compared to Penicillium sp., and Fusarium sp $(\mathrm{Zn}>\mathrm{Ni}>\mathrm{Pd}>\mathrm{Cd})$. Tolerance of toxic metals is based on ionic species associating with the cell surface or extra cellular polysacharides, proteins and chitins (Volesky, 1990). Our preliminary findings indicate that fungus such as $P$. chrysosporium , Aspergillus niger, Aspergillus sp., Fusarium sp., and Penicillium $s p$ have heavy metal tolerance capacity and also it reduces the heavy metal concentration in the contaminated solid waste.

Table 1. Potential of fungus in heavy metal bioremediation

\begin{tabular}{|c|c|c|c|}
\hline S. NO & Fungus & $\begin{array}{l}\text { Heavy } \\
\text { metals }\end{array}$ & References \\
\hline 1 & A. flavus & $\mathrm{Pb}$ & (Seema Dwivedi et al., 2012) \\
\hline 2 & A. sydoni, & $\mathrm{Cr}(\mathrm{VI})$ & (Bishnoi et al., 2007 ) \\
\hline 3 & $\begin{array}{l}\text { Aspergillus } \\
\text { Luchuensis }\end{array}$ & $\begin{array}{l}\mathrm{Cu}, \\
\mathrm{Cd}\end{array}$ & (El-Gendy et al., 2011) \\
\hline 4 & $\begin{array}{c}\text { Aspergillus } \\
\text { Nidulans }\end{array}$ & As & (Maheswari and Murugesan, 2009) \\
\hline 5 & $\begin{array}{c}\text { Aspergillus } \\
\text { niger }\end{array}$ & $\begin{array}{l}\mathrm{Cd}, \mathrm{Pb}, \mathrm{Zn}, \\
\mathrm{Cu}, \mathrm{Ni}, \mathrm{Cr} \\
\quad \mathrm{As}\end{array}$ & $\begin{array}{l}\text { (Pal et al., 2010; Junior et al., 2003; Amini et al., } \\
\text { 2009;Ahmad et al., 2005a; Kumar et al., 2011; } \\
\text { Thippeswamy et al., 2012a; Faryal et al., 2007; } \\
\text { Shoaib et al., 2012; Rao et al., 1993; Venkobacher, } \\
\text { 1990; Joshi et al., 2011; Adeyemi, 2009) }\end{array}$ \\
\hline 6 & $\begin{array}{l}\text { Aspergillus } \\
\text { ochraceous }\end{array}$ & $\mathrm{Cr}$ & (seshikala and Charya, 2012) \\
\hline 7 & $\begin{array}{c}\text { Aspergillus } \\
\text { Oryzae }\end{array}$ & $\mathrm{Cr}$ & (Nasseri et al., 2002) \\
\hline 8 & $\begin{array}{c}\text { Aspergillus } \\
\text { terrus }\end{array}$ & $\begin{array}{l}\mathrm{Pb}, \mathrm{Cu}, \mathrm{Ni}, \\
\mathrm{Cr}\end{array}$ & $\begin{array}{c}\text { (Joshi et al., 2011; Shoaib et al., 2012; Varshney et } \\
\text { al., 2010; Seshikalai and Charya, 2012) }\end{array}$ \\
\hline 9 & $\begin{array}{l}\text { Aspergillus } \\
\text { Tubingensis }\end{array}$ & $\mathrm{Cu}, \mathrm{Cd}$ & (El-Gendy et al., 2011) \\
\hline 10 & $\begin{array}{c}\text { Aspergillus } \\
\text { Ustus }\end{array}$ & $\mathrm{Zn}, \mathrm{Cu}$ & (Chandrakar et al., 2012) \\
\hline 11 & Aspergillus flavus & $\begin{array}{l}\mathrm{Pb}(\mathrm{II}) \\
\mathrm{Cu}(\mathrm{II})\end{array}$ & (Akar and Tunali, 2006) \\
\hline 12 & Aspergillus flavus & $\begin{array}{l}\mathrm{Zn}, \mathrm{Cu}, \mathrm{Ni} \\
\mathrm{Pb}\end{array}$ & $\begin{array}{l}\text { (Chandrakar et al., 2012; Thippeswamy et al., } \\
\text { 2012a; Shoaib et al., 2012) }\end{array}$ \\
\hline 13 & Aspergillus foetidus & $\mathrm{Cr}(\mathrm{VI})$ & (Shankar Congeevaram et al., 2007) \\
\hline 14 & Aspergillus foetidus & $\mathrm{Cr}$ & (Prasenjit and Sumathi, 2005) \\
\hline 15 & Aspergillus fumigatus & $\begin{array}{l}\mathrm{Cu}, \mathrm{Cd} \\
\mathrm{Co}, \mathrm{Ni}, \mathrm{Pb}\end{array}$ & (Rao et al., 1993; Ramasamy et al., 2011) \\
\hline 16 & Aspergillus niger, & $\mathrm{Cr}(\mathrm{VI})$ & (Bishnoi et al., 2007) \\
\hline 17 & Aspergillus oryzae & $\mathrm{Cr}(\mathrm{III})$ & (Shankar Congeevaram et al., 2007) \\
\hline 18 & Aspergillus parasiticus & $\mathrm{Pb}(\mathrm{II})$ & ( Akar et al., 2007) \\
\hline 19 & Aspergillus sp. & $\begin{array}{l}\mathrm{Cd}, \mathrm{Cr}, \mathrm{Pb}, \\
\mathrm{Zn}, \mathrm{Cu}\end{array}$ & $\begin{array}{c}\text { (Kumar et al., 2011; (Khan et al., 1998; Zafar et al., } \\
\text { 2007; Congeevaram et al., 2007; Sen and } \\
\text { Dastidar, 2007; Sen and Dastidar, 2010; Tahir, } \\
2012 \text { ) }\end{array}$ \\
\hline
\end{tabular}




\begin{tabular}{|c|c|c|c|}
\hline 20 & Aspergillus species & $\begin{array}{l}\mathrm{Cr}, \mathrm{Ni}, \mathrm{Fe}, \\
\mathrm{Zn}, \mathrm{Pb}\end{array}$ & (Ramesh et al., 2014) \\
\hline 21 & Aspergilus niger & $\begin{array}{l}\mathrm{Cd}, \mathrm{Zn} \mathrm{Zn}, \\
\mathrm{Ag}, \mathrm{Th}, \mathrm{U}\end{array}$ & $\begin{array}{c}\text { (Congeevaram et al., 2007; Gunasekaran et al., } \\
\text { 2003; Ashok Kumar et al., 2011) }\end{array}$ \\
\hline 22 & Botrytis cinerea & $\begin{array}{l}\mathrm{Zn}(I I), \\
\mathrm{Pb}(\mathrm{II})\end{array}$ & (Tunali and Akar, 2006) \\
\hline 23 & brown-rot fungus lentinus edodes & $\mathrm{Cd}$ & (Chen et al., 2008) \\
\hline 24 & Candida tropicalis & $\mathrm{Zn}$ & (Akhtar et al., 2008) \\
\hline 25 & Candida sp. & $\mathrm{Cu}, \mathrm{Zn}, \mathrm{Fe}$ & (Anaemene, 2012) \\
\hline 26 & Candida utilis & $\mathrm{Cr}$ & (Pattanapipitpaisal et al., 2001) \\
\hline 27 & Cephalosporium aphidicola & $\mathrm{Pb}(\mathrm{II})$ & (Tunali et al., 2006) \\
\hline 28 & cerevisae & $\begin{array}{l}\mathrm{Cd}, \mathrm{Ni}, \mathrm{Pb} \\
\mathrm{Cr}, \mathrm{Zn}, \mathrm{Cu}\end{array}$ & $\begin{array}{c}\text { (Damodaran et al., 2011; Huang et al., 1990; } \\
\text { Thippeswamy et al., 2012b; Prakasham et al., } \\
\text { 1998; Volesky, 1992) }\end{array}$ \\
\hline 29 & $\begin{array}{l}\text { Cladosporium } \\
\text { Resinae }\end{array}$ & $\mathrm{Cu}$ & (Gadd and De Rome, 1988) \\
\hline 30 & Cladosporium sp. & $\mathrm{Zn}, \mathrm{Cu}$ & (Chandrakar et al., 2012; Khan et al., 1998) \\
\hline 31 & Clavispora & $\mathrm{Cd}$ & (El-Gendy et al., 2011) \\
\hline 32 & $\begin{array}{l}\text { Curvularia } \\
\text { Lunata }\end{array}$ & $\mathrm{Cu}, \mathrm{Cd}, \mathrm{Cr}$ & $\begin{array}{l}\text { (El-Gendy et al., 2011; Seshikala and Charya, } \\
\text { 2012) }\end{array}$ \\
\hline 33 & $\begin{array}{l}\text { Dactylosporium } \\
\text { sp. }\end{array}$ & $\mathrm{Cr}$ & (Seshikala and Charya, 2012) \\
\hline 34 & $\begin{array}{l}\text { Drechslera } \\
\text { hawaiiensis }\end{array}$ & $\mathrm{Cu}, \mathrm{Cd}$, & (El-Gendy et al., 2011) \\
\hline 35 & $\begin{array}{c}\text { Drechslera } \\
\text { Rostrata }\end{array}$ & $\mathrm{Cr}$ & (Seshikala, and Charya, 2012) \\
\hline 36 & Fungicola & $\mathrm{Cd}$ & (El-Gendy et al., 2011) \\
\hline 37 & Fusarium sp. & $\begin{array}{c}\mathrm{Co}, \underset{\mathrm{Ni}}{\mathrm{Cr}} \mathrm{Cd} \\
\end{array}$ & (Shaheen Zafar et al., 2007) \\
\hline 38 & Ganoderma carnosum & $\mathrm{Pb}(\mathrm{II})$ & (Akar et al., 2007) \\
\hline 39 & Geotrichum sp. & $\begin{array}{l}\mathrm{Co}, \mathrm{Cr}, \mathrm{Cd} \\
\mathrm{Ni}\end{array}$ & (Shaheen Zafar et al., 2007) \\
\hline 40 & Gliocladium sp. & $\mathrm{Cu}$ & (Tahir, 2012) \\
\hline 41 & Harzianum & $\mathrm{Ni}, \mathrm{Cr}$ & $\begin{array}{c}\text { (Shoaib, 2012) } \\
\text { (Sarkar et al., 2010) }\end{array}$ \\
\hline 42 & Hymenoscyphus ericae, & $\mathrm{Hg}(\mathrm{II})$ & (Kelly et al., 2006) \\
\hline 43 & $\begin{array}{l}\text { Metarrhizium } \\
\text { Anisopliae }\end{array}$ & $\mathrm{Pb}$ & (Ismail et al., 2005) \\
\hline 44 & $\begin{array}{l}\text { Monacrosporium } \\
\text { elegans }\end{array}$ & $\mathrm{Cu}, \mathrm{Cd}$ & (El-Gendy et al., 2011) \\
\hline 45 & Monilia sp. & $\underset{\mathrm{Co}, \mathrm{Cr}}{\mathrm{Ni}} \mathrm{Cd}$ & (Shaheen Zafar et al., 2007) \\
\hline
\end{tabular}




\begin{tabular}{|c|c|c|c|}
\hline 46 & Neocosmospora vasinfecta, & $\mathrm{Hg}(\mathrm{II})$ & (Kelly et al., 2006) \\
\hline 47 & $\begin{array}{c}\text { Neurospora } \\
\text { crassa }\end{array}$ & $\mathrm{Pb}, \mathrm{Cu}$ & (Ismail et al., 2005) \\
\hline 48 & Neurospora crassa & $\begin{array}{l}\mathrm{Pb}(\mathrm{II}), \\
\mathrm{Cu}(\mathrm{II})\end{array}$ & (Kiran et al., 2005) \\
\hline 49 & $\begin{array}{l}\text { Penicillium } \\
\text { canescens }\end{array}$ & $\mathrm{Cd}, \mathrm{Pb}, \mathrm{As}$ & (Say et al., 2003) \\
\hline 50 & $\begin{array}{l}\text { Penicillium } \\
\text { chrysogenum }\end{array}$ & $\begin{array}{l}\mathrm{Cr}, \mathrm{Ni} \\
\mathrm{Cu}, \mathrm{U}, \mathrm{Th} \\
\mathrm{Zn}, \mathrm{Pb}, \mathrm{Cd}\end{array}$ & $\begin{array}{c}\text { (Tan and Cheng, 2003; Skowronski, 2001; Tsezos } \\
\text { and Volesky, 1981; Niu et al., 1993) }\end{array}$ \\
\hline 51 & $\begin{array}{l}\text { Penicillium } \\
\text { Cyclopium }\end{array}$ & $\mathrm{Cu}$ & (lanis et al., 2006) \\
\hline 52 & $\begin{array}{l}\text { Penicillium } \\
\text { decumbens }\end{array}$ & $\mathrm{Cd}, \mathrm{Ni}, \mathrm{Cr}$ & (Levinskaite, 2001) \\
\hline 53 & $\begin{array}{l}\text { Penicillium } \\
\text { digitatum }\end{array}$ & $\mathrm{Cd}, \mathrm{Cu}, \mathrm{Pb}$ & (Galun et al., 1987) \\
\hline 54 & $\begin{array}{l}\text { Penicillium } \\
\text { duclauxi }\end{array}$ & $\mathrm{Cu}, \mathrm{Cd}$ & (El-Gendy et al., 2011) \\
\hline 55 & $\begin{array}{l}\text { Penicillium } \\
\text { lilacium }\end{array}$ & $\mathrm{Cu}, \mathrm{Cd}$ & ( El-Gendy et al., 2011) \\
\hline 56 & $\begin{array}{l}\text { Penicillium } \\
\text { Notatum }\end{array}$ & $\mathrm{Cr}$ & ( Seshikala and Charya, 2012) \\
\hline 57 & $\begin{array}{c}\text { Penicillium } \\
\text { Pupurogenum }\end{array}$ & $\mathrm{Cr}$ & (Say et al., 2003 ) \\
\hline 58 & $\begin{array}{c}\text { Penicillium } \\
\text { Simplicissimum }\end{array}$ & $\mathrm{Cd}, \mathrm{Zn}, \mathrm{Pb}$ & (Fan et al., 2008) \\
\hline 59 & $\begin{array}{l}\text { Penicillium } \\
\text { Spinulosum }\end{array}$ & $\mathrm{Zn}$ & ( Townsley and Ross, 1985) \\
\hline 60 & Penicillium janthinellum & $\mathrm{Cr}(\mathrm{VI})$ & (Bishnoi et al., 2007) \\
\hline 61 & Penicillium sp. & 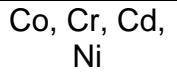 & (Shaheen Zafar et al., 2007) \\
\hline 62 & Penicillium sp. & $\begin{array}{l}\mathrm{Cr}, \mathrm{Cd}, \mathrm{Ni}, \\
\mathrm{Zn}, \mathrm{Cu}, \mathrm{Pb}\end{array}$ & $\begin{array}{l}\text { (Ahmad et al., 2005a; Khan et al.1998; Dugal and } \\
\text { Gangawane, 2012; Velmurugan et al., 2010; Tahir, } \\
\text { 2012) }\end{array}$ \\
\hline 63 & Pestalotiopsis & $\mathrm{Cd}$ & ( El-Gendy et al., 2011) \\
\hline 64 & $\begin{array}{c}\text { Pyrenocheta } \\
\text { Cajani }\end{array}$ & $\mathrm{Cr}$ & ( Seshikala and Charya 2012) \\
\hline 65 & Rhizopus sp. & $\begin{array}{c}\mathrm{Co}, \underset{\mathrm{Ni}}{\mathrm{Cr}} \mathrm{Cd}, \\
\text {, }\end{array}$ & (Seshikala and Charya 2012) \\
\hline 66 & Saccharomyces & $\mathrm{Cd}$ & ( Thippeswamy et al., 2012b) \\
\hline 67 & Sarcinella sp. & $\mathrm{Zn}, \mathrm{Cu}$ & (Chandrakar et al., 2012) \\
\hline
\end{tabular}




\begin{tabular}{|c|c|c|c|}
\hline 68 & $\begin{array}{c}\text { Talaromyces } \\
\text { helicus }\end{array}$ & $\mathrm{Cu}$ & ( Romero et al., 2006) \\
\hline 69 & $\begin{array}{c}\text { Trichoderma } \\
\text { Atroviride }\end{array}$ & $\mathrm{Zn}$ & (Yazdani et al., 2010) \\
\hline 70 & Trichoderma & $\mathrm{Cu}$ & ( Shoaib et al., 2012) \\
\hline 71 & Trichoderma Longbrachiatum & $\mathrm{Cr}$ & ( Joshi et al., 2011) \\
\hline 72 & $\begin{array}{c}\text { Trichoderma } \\
\text { Virde }\end{array}$ & $\begin{array}{c}\mathrm{Pb}, \mathrm{Ni}, \mathrm{Cd}, \\
\mathrm{Cr}\end{array}$ & $\begin{array}{c}\text { (Prasad et al., 2013; Levinskaite 2001; Joshi et al., } \\
\text { 2011; Seshikala and Charya, 2012; Hala and } \\
\text { Eman, 2009) }\end{array}$ \\
\hline 73 & Trichoderma sp. & $\begin{array}{l}\text { Co, } \underset{\mathrm{Ni}}{\mathrm{Cr}} \mathrm{Cd}, \\
\end{array}$ & (Shaheen Zafar et al., 2007) \\
\hline 74 & Trichoderma sp. & $\begin{array}{l}\mathrm{Cu} \\
\mathrm{Pb} \\
\mathrm{Cr}\end{array}$ & ( Khan et al., 1998; Vankar and Bajpai, 2007) \\
\hline 75 & Trichoderma viride, & $\mathrm{Cr}(\mathrm{VI})$ & (Bajgai et al., 2012) \\
\hline 76 & $\begin{array}{c}\text { Trichosporon } \\
\text { Cutaneum }\end{array}$ & $\mathrm{Cr}$ & ( Bishnoi et al., 2007) \\
\hline 77 & Verticillium & $\mathrm{Cu}$ & (El-Gendy et al., 2011) \\
\hline 78 & Verticillium Terrestre & $\mathrm{Hg}(\mathrm{II})$ & (Kelly et al., 2006) \\
\hline 79 & $\begin{array}{c}\text { white-rot basidiomycete, } \\
\text { Phanerochaete chrysosporium }\end{array}$ & $\mathrm{Pb}$ & (Huang et al., 2008) \\
\hline 80 & white-rot fungus & $\mathrm{Pb}$ & (Guang Ming Zeng et al., 2007) \\
\hline
\end{tabular}

\subsection{Mechanism Involved In Fungus}

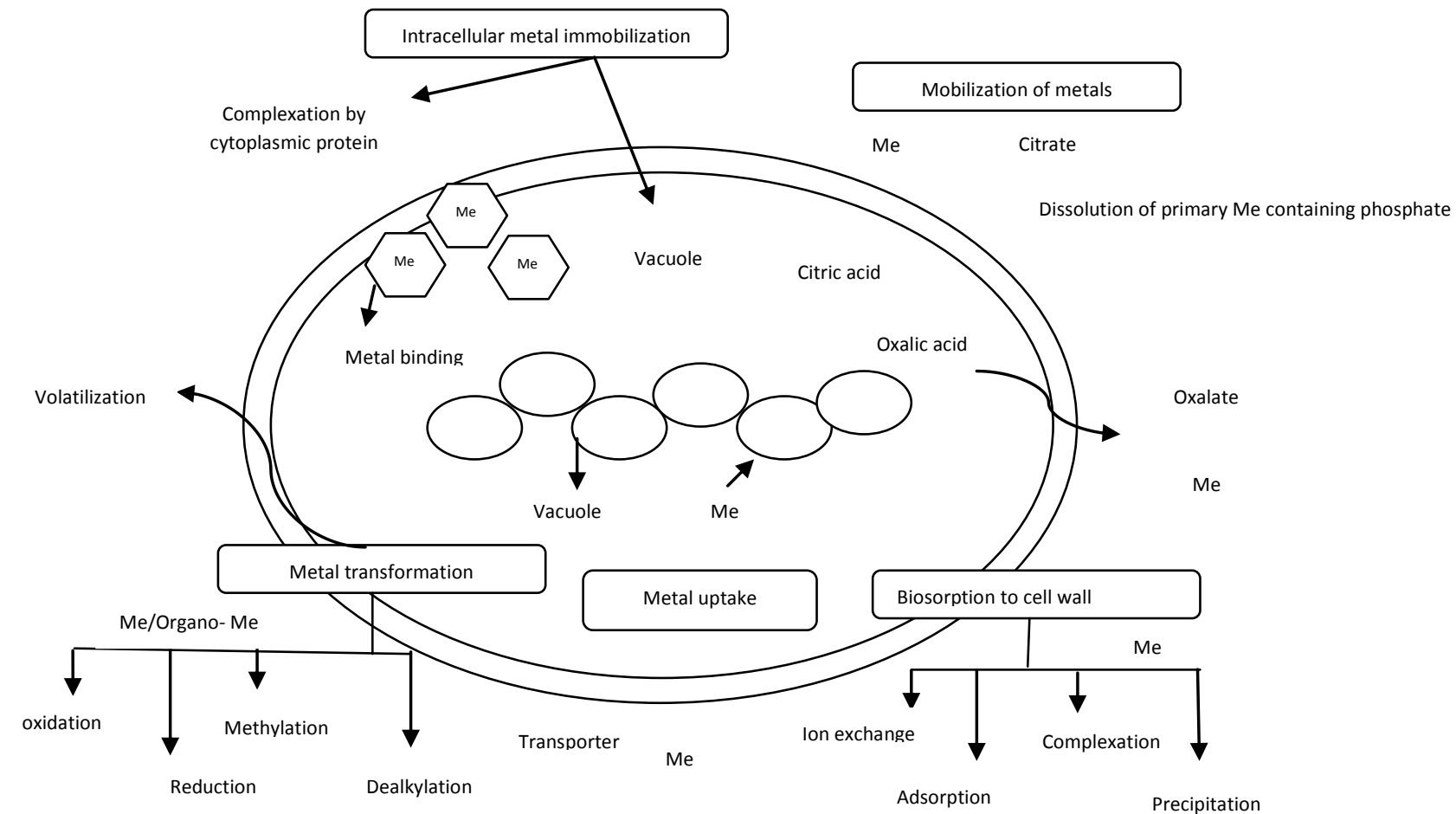

Fig 1: fungi-metal interactions (Gadd, 1993; Harms et al., 2011; Valls and de Lorenzo, 2002) 
- The metals are mobilized due to the production and excretion of fungal products such as citric acid and oxalic acid. The citric acid acts as an efficient metal ions chelator and the oxalic acid interact with metal ions to produce insoluble oxalate, resulted from the dissolution of primary metals containing phosphate. The metal solubility may be increased by these organic acids by means of mycosphere acidification and production of metal-complex structure.

- In the process of Bio-sorption, the metals are first interact with cell wall of the fungus, this cellular component play an important roles as a protective layer and barrier that control the uptake of toxic metals into the cell. A complex mechanism is involved in the Interaction of metal with fungal cell wall which includes several processes such as ion exchange, complexation, crystallization, adsorption and precipitation and also influenced by the biomass concentration and chemical behaviour of the metals.

- Specific transporters are responsible for the uptake of metals. These transporters react with other type of metals. Carriers may consist of all the metabolically-coupled and $\mathrm{H}_{+}$- gradient driven transport system.

- Two processes are involved in Intracellular metal immobilization, they are

Metallothioneins - vacuoles compartmentation and complexation by cytoplasmic protein

phytochelatins - a rich SH peptide .

In the process of Metallothioneins, the metal-binding protein that can modulate the intracellular concentrations and bind both the essential metal such as $\mathrm{Cu}$ and $\mathrm{Zn}$ and inessential metal such as Cd. Fungal vacuole plays a major roles in molecular degradation, storage of metabolites, regulation of cytosolic concentrations of metal ions and detoxifies potentially toxic metal ions.

- Biotransformation of the metals in fungus is make possible through various chemical reactions such as oxidation, reduction, methylation and dealkylation. These are the major reactions which may lead to metal volatilization and reduce the metal toxicity. Metals may also transfer to the other parts of the fungi mycelium and plant symbionts by cytosplasmic vesicles and vacuoles.

\section{ENHANCEMENT OF MYCOREMEDIATION BY VERMICOMPOSTING}

Vermicomposting is one of the most effective biotechnology process, for the solid waste treatment. This process converting the solid waste into useful and environmental friendly end product. After the treatment of Mycoremediation, the remediated products can be undergone for vermicomposting. In the process of vermicomposting, the earthworm has been used for the conversion of urban, industrial and agro-industrial wastes to Biofertilizer. The earthworm acts as the blenders and they modify its biological, physical and chemical properties of the feed mixtures. Gradually decreasing the C: $\mathrm{N}$ ratios, increasing the surface exposed to microorganisms and further decomposition. Many researchers report that the earthworm could not tolerate the fresh industrial solid waste, so it can be spiked with different types of substrate to reduce the toxicity of industrial solid waste to the earthworm. Additional of at least $30 \%$ cow dung (on dry weight basis) was essential for the survival of the earthworm in the solid textile mill sludge (STMS) (Priya Kaushik and Garg, 2003). The study established that the potential of earthworm in devour of metals available in the sandy soil (Zorn et al., 2005). The mobility and solubility of the metals in soil may be affected by the microbial activity (Gadd, 1996). Microbes play an very important role in the immobilization of metals. It is well known that the earthworm activities increases the population of microbes and that the microbial communities are native to the earthworm species (Parle, 1963; Toyota and Kirmura, 2000). That the bacterial cells have the high ratio of surface area to volume, which provides storng capacity of adsorbing and immobilizing heavy metals (Beveridge and Schultze-Lam, 1995). It is well established fact that the earthworm activites increases the nitrogen in the cast through the microorganisms present in their gut (Ndegwa and Thompson, 2001). Many studies found that the final Vermicomposted product have the higher P and K concentration (Beveridge and Schultze-Lam, 1995). The final NPK content in the vermicompost is mainly dependent on the initial Nitrogen present in the feed material and the degree of decomposition (Benitez et al., 1999). The studies showed that textile mill sludge spiked with poultry droppings in different ratios using epigeic worm Eisenia fetida, shows the heavy metals ( $\mathrm{Fe}, \mathrm{Zn}, \mathrm{Pb}$ and $\mathrm{Cd}$ ) contents were lower in the final feed mixture than compared to the initial feed mixture (Crawford., 1983). During vermicomposting, earthworms maintain aerobic conditions in waste through burrowing, inverting and biochemical processes, which are improved by microbial decomposition of the substrate in the intestine of the earthworm (Garg and Priya Kaushik, 2005). Several reports are existing on the use of earthworms in composting sewage sludge and it has been recognized that epigeic forms of earthworm hasten the composting process with production of better quality of vermicompost as compared to traditional composting method (Majumdar et al., 2006). The report revealed the efficiency of Eisenia andrei (Bouche) in bioconverting paper-pulp mill sludge mixed with primary sewage sludge. The mixture at a ratio of 3:1 was a suitable medium for optimum growth and reproduction of the earthworms. The earthworms accelerated the mineralization of organic matter, favored the breakdown of structural polysaccharides and increased the humification rate (Ghosh et al., 1999). Solid paper-mill sludge mixed with sewage sludge in 3:2 ratio resulted in the highest growth rate and the lowest mortality of Eisenia andrei, whereas paper mill sludge mixed with pig slurry exhibited a high mortality (Elvira et al., 1996). The growth and reproduction of Eisenia andrei in mixed paper-pulp mill sludge and cattle waste found that, the number of earthworms increased between 22- and 36-fold and total biomass increased between 2.2- and 3.9-fold in different feed mixtures(Elvira et al., 1998). In the vermicomposting of activated sludge observed that approximately $1.0 \mathrm{~g}$ worm could ingest $4.0 \mathrm{~g}$ of activated sludge in 5 days (Hartenstein and Hartenstein, 1981). The textile mill sludge can be potentially useful as raw substrate in vermicomposting if mixed up to $30 \%$ with cow dung (Harms et al., 2011). E. foetida is an epigeic 
earthworm species which lives in organic wastes and requires high moisture content, adequate amounts of suitable organic material and dark conditions for proper growth and development (Hartenstein and Hartenstein, 1981; Gunadi

and Edwards, 2003; Gunadi et al., 2002; Chaudhari and Bhattacharjee, 2002). In order to utilize this species successfully in vermicomposting, its survival, growth and fecundity in different wastes should be known. Vermicomposting is the usual method that managed by earthworms and in addition to decomposing of organic waste, the availability of heavy metals decreases due to bioaccumulation of these metals and organo-complex formation during this process (Ghyasvand et al., 2008).

TABLE 2. HEAVY METAL REDUCTION EFFICIENCY OF VARIOUS EARTHWORM SPECIES

\begin{tabular}{|c|c|c|c|c|c|c|c|c|c|}
\hline $\begin{array}{l}\text { Specie } \\
\text { s }\end{array}$ & 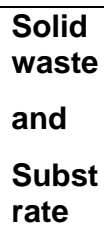 & $\begin{array}{l}\text { Duration } \\
\text { of } \\
\text { Experimen } \\
t\end{array}$ & $\begin{array}{l}\text { Different } \\
\text { Mixtures of } \\
\text { substrate and } \\
\text { solid waste }\end{array}$ & $\begin{array}{l}\text { Reduction } \\
\text { level of } \\
\text { copper }\end{array}$ & $\begin{array}{l}\text { Reducti } \\
\text { on level } \\
\text { of } \\
\text { Zinc }\end{array}$ & $\begin{array}{l}\text { Reduction } \\
\text { level of } \\
\text { cadmium }\end{array}$ & $\begin{array}{l}\text { Reduction } \\
\text { level of } \\
\text { chromium }\end{array}$ & $\begin{array}{l}\text { Reduction } \\
\text { level of } \\
\text { Lead }\end{array}$ & $\begin{array}{l}\text { Referen } \\
\text { ce }\end{array}$ \\
\hline $\begin{array}{l}\text { Eisenia } \\
\text { fetida }\end{array}$ & $\begin{array}{l}\text { Solid } \\
\text { Textil } \\
\text { e mill } \\
\text { sludg } \\
\text { e } \\
\text { (STM } \\
\text { S) } \\
\text { and } \\
\text { cow } \\
\text { dung } \\
\text { (CD) }\end{array}$ & 90 days & $\begin{array}{l}\text { CD + STMS }(g) \\
1000+0 \\
900+100 \\
800+200 \\
700+300 \\
600+400 \\
500+500 \\
400+300 \\
300+700\end{array}$ & $\begin{array}{l}(\mathrm{mg} / \mathrm{kg}) \\
19-24 \\
19-19 \\
18-19 \\
22-25 \\
23-25 \\
19-19 \\
26-27 \\
30-31\end{array}$ & $\begin{array}{l}(\mathrm{mg} / \mathrm{kg}) \\
196-150 \\
186-115 \\
191-169 \\
183-158 \\
186-118 \\
190-164 \\
201-169 \\
190-119\end{array}$ & DN & $\begin{array}{l}(\mathrm{mg} / \mathrm{kg}) \\
4-4 \\
17-13 \\
16-12 \\
17-13 \\
16-12 \\
16-12 \\
16-12 \\
15-12\end{array}$ & DN & $\begin{array}{l}\text { ( Priya } \\
\text { Kaushik } \\
\text { and } \\
\text { Garg, } \\
\text { 2003) }\end{array}$ \\
\hline $\begin{array}{l}\text { Iranian } \\
\text { Eisenia } \\
\text { fetida }\end{array}$ & $\begin{array}{l}\text { Sewa } \\
\text { ge } \\
\text { Sludg } \\
\text { e } \\
\text { (SS) } \\
\text { and } \\
\text { saw } \\
\text { dust } \\
\text { (SD) }\end{array}$ & 60 days & $\begin{array}{l}\mathrm{SS}+\mathrm{SD}(\mathrm{kg}) \\
7+1\end{array}$ & $\begin{array}{l}(\mathrm{mg} / \mathrm{kg}) \\
\\
380.1- \\
215.2\end{array}$ & $\begin{array}{l}(\mathrm{mg} / \mathrm{kg}) \\
\\
390.7- \\
206.2\end{array}$ & $\begin{array}{l}(\mathrm{mg} / \mathrm{kg}) \\
17.4-8.6\end{array}$ & $\begin{array}{l}(\mathrm{mg} / \mathrm{kg}) \\
108-38\end{array}$ & $\begin{array}{l}(\mathrm{mg} / \mathrm{kg}) \\
184.4-75.6\end{array}$ & $\begin{array}{l}\text { ( } \\
\text { Shahma } \\
\text { nsouri } \\
\text { et al., } \\
\text { 2005) }\end{array}$ \\
\hline $\begin{array}{l}\text { Austral } \\
\text { ian } \\
\text { Eisenia } \\
\text { fetida }\end{array}$ & $\begin{array}{l}\text { Sewa } \\
\text { ge } \\
\text { Sludg } \\
\text { e } \\
\text { (SS) } \\
\text { and } \\
\text { saw } \\
\text { dust } \\
\text { (SD) }\end{array}$ & 60 days & $\begin{array}{l}\mathrm{SS}+\mathrm{SD}(\mathrm{kg}) \\
7+1\end{array}$ & $\begin{array}{l}(\mathrm{mg} / \mathrm{kg}) \\
380.1- \\
225.8\end{array}$ & $\begin{array}{l}(\mathrm{mg} / \mathrm{kg}) \\
\\
390.7- \\
219.9\end{array}$ & $\begin{array}{l}(\mathrm{mg} / \mathrm{kg}) \\
17.4-7.1\end{array}$ & $\begin{array}{l}(\mathrm{mg} / \mathrm{kg}) \\
108-35\end{array}$ & $\begin{array}{l}(\mathrm{mg} / \mathrm{kg}) \\
\\
184.4 \\
70.4\end{array}$ & $\begin{array}{l}\text { ( } \\
\text { Shahma } \\
\text { nsouri } \\
\text { et al., } \\
\text { 2005) }\end{array}$ \\
\hline $\begin{array}{l}\text { Lampit } \\
\text { o } \\
\text { mauritii } \\
\text { (Kinber } \\
\text { g) }\end{array}$ & $\begin{array}{l}\text { Synth } \\
\text { etic } \\
\text { Conta } \\
\text { minat } \\
\text { ed } \\
\text { soil } \\
\text { (SCS) } \\
\text { and } \\
\text { farm }\end{array}$ & 30 days & $\begin{array}{l}\text { SCS + FYM } \\
(300 \mathrm{~g}) \\
1: 9\end{array}$ & DN & $\begin{array}{l}(\mathrm{mg} / \mathrm{kg}) \\
\\
75 \quad- \\
34.26 \\
150 \quad- \\
72.86 \\
300 \quad-\end{array}$ & DN & DN & $\begin{array}{l}(\mathrm{mg} / \mathrm{kg}) \\
75-40.78 \\
150-81.44 \\
300 \\
158.15\end{array}$ & $\begin{array}{l}\text { (Sulata } \\
\text { Maity et } \\
\text { al., } \\
\text { 2010) }\end{array}$ \\
\hline
\end{tabular}




\begin{tabular}{|c|c|c|c|c|c|c|c|c|c|}
\hline & $\begin{array}{l}\text { yard } \\
\text { manu } \\
\text { re } \\
\text { (FYM) }\end{array}$ & & & & 152.15 & & & & \\
\hline $\begin{array}{l}\text { Eisenia } \\
\text { fetida, }\end{array}$ & $\begin{array}{l}\text { paper } \\
\text { mill } \\
\text { waste } \\
\text { water } \\
\text { sludg } \\
\text { e } \\
\text { (PMS } \\
\text { ) and } \\
\text { cow } \\
\text { dung } \\
\text { (CD) }\end{array}$ & 60 days & $\begin{array}{l}C D: P M S \\
(400 \mathrm{~g}) \\
1: 0 \\
3: 1 \\
2: 1 \\
1: 1 \\
0: 1 \\
1: 3 \\
2: 1\end{array}$ & $\begin{array}{l}(\mathrm{mg} / \mathrm{kg}) \\
110.5 \\
23.75 \\
115.5- \\
36.06 \\
114.5- \\
25.95 \\
129.5- \\
26.12 \\
144.4- \\
16.79 \\
142.3- \\
23.50 \\
123.5- \\
18.64\end{array}$ & DN & $\begin{array}{l}(\mathrm{mg} / \mathrm{kg}) \\
9.29-7.91 \\
8.77-7.89 \\
8.75-7.90 \\
8.71-7.89 \\
8.75-7.90 \\
8.67-7.91 \\
8.64-7.89\end{array}$ & $\begin{array}{l}(\mathrm{mg} / \mathrm{kg}) \\
124.4-65.6 \\
121.4-23.2 \\
114.2-25.6 \\
128.3-32.3 \\
187.3-43.6 \\
175.3-39.3 \\
158.7-32.0\end{array}$ & $\begin{array}{l}(\mathrm{mg} / \mathrm{kg}) \\
59.6-2.0 \\
45.6-2.0 \\
42.3-1.41 \\
49.7-1.53 \\
62.5-1.54 \\
42.8-2.0 \\
35.4-1.66\end{array}$ & $\begin{array}{l}\text { Surindra } \\
\text { Suthar } \\
\text { et al., } \\
\text { 2014) }\end{array}$ \\
\hline $\begin{array}{l}\text { Lumbri } \\
\text { cus } \\
\text { rubellu } \\
s\end{array}$ & $\begin{array}{l}\text { Cow } \\
\text { dung } \\
\text { (CD), } \\
\text { Kitche } \\
n \\
\text { waste } \\
\text { (KW) } \\
\text { and } \\
\text { coffee } \\
\text { groun } \\
\text { d } \\
\text { (CG) }\end{array}$ & 30 weeks & $\begin{array}{l}\mathrm{CD}: \mathrm{KW} \\
30: 70 \\
\mathrm{CD}: \mathrm{CG} \\
30: 70 \\
\mathrm{CD}: \mathrm{KW}: \mathrm{CG} \\
30: 35: 35\end{array}$ & $\begin{array}{l}0.006 \% \\
0.003 \% \\
0.007 \%- \\
0.002 \% \\
0.005 \% \quad \text { to } \\
0.002 \%\end{array}$ & $\begin{array}{l}0.015 \% \\
-0.02 \% \\
0.016 \% \\
-0.01 \% \\
0.012 \%- \\
0.01 \%\end{array}$ & DN & DN & DN & $\begin{array}{l}\text { (Adi } \\
\text { ainurza } \\
\text { man } \\
\text { Jamalud } \\
\text { in and } \\
\text { Noor } \\
\text { Zalina } \\
\text { Mahmo } \\
\text { od, } \\
\text { 2010) }\end{array}$ \\
\hline $\begin{array}{l}\text { Califor } \\
\text { nian } \\
\text { earthw } \\
\text { orm } \\
\text { Eisenia } \\
\text { fetida, }\end{array}$ & $\begin{array}{l}\text { Sewa } \\
\text { ge } \\
\text { sludg } \\
\text { e }\end{array}$ & 70 days & $\begin{array}{l}\text { Sewage sludge } \\
60 \mathrm{~kg}\end{array}$ & $\begin{array}{l}(\mathrm{mg} / \mathrm{kg}) \\
\\
181.44- \\
120.8\end{array}$ & DN & DN & $\begin{array}{l}(\mathrm{mg} / \mathrm{kg}) \\
\\
284.48- \\
92.62\end{array}$ & DN & $\begin{array}{l}\text { (Ausra } \\
\text { Zigmont } \\
\text { iene } \\
\text { and } \\
\text { Indre } \\
\text { Liberyte } \\
\text {, 2014) }\end{array}$ \\
\hline $\begin{array}{l}\text { Eudrilu } \\
\text { s } \\
\text { eugeni } \\
\text { ae }\end{array}$ & $\begin{array}{l}\text { Munic } \\
\text { ipal } \\
\text { Solid } \\
\text { Wast } \\
\text { e } \\
\text { (MSW } \\
\text { ), } \\
\text { Marke } \\
\text { t } \\
\text { Wast } \\
\text { e } \\
\text { (MW) } \\
\text { and } \\
\text { Flowe } \\
\text { r } \\
\text { Wast } \\
\text { e (FW }\end{array}$ & 60 days & $\begin{array}{l}1: 3(\mathrm{c}: M S W) \\
1: 3(\mathrm{c}: \mathrm{MW}) \\
1: 3(\mathrm{c}: \mathrm{FW})\end{array}$ & $\begin{array}{l}89.2 \% \\
95.1 \% \\
95.3 \%\end{array}$ & $\begin{array}{l}94 \% \\
87.9 \% \\
94.7 \%\end{array}$ & $\begin{array}{l}89.5 \% \\
88.7 \% \\
84.1 \%\end{array}$ & DN & $\begin{array}{l}94.4 \% \\
96.1 \% \\
95.6 \%\end{array}$ & $\begin{array}{l} \\
\text { ( Swathi } \\
\text { Pattnaik } \\
\text { and } \\
\text { Vikram } \\
\text { Reddy, } \\
\text { 2009) }\end{array}$ \\
\hline $\begin{array}{l}\text { Eisenia } \\
\text { fetida }\end{array}$ & $\begin{array}{l}\text { Munic } \\
\text { ipal } \\
\text { Solid }\end{array}$ & 60 days & $\begin{array}{l}\text { 1:3(c:MSW) } \\
1: 3(\mathrm{c}: M W)\end{array}$ & $\begin{array}{l}86.6 \% \\
87.3 \%\end{array}$ & $\begin{array}{l}91.0 \% \\
85.2 \%\end{array}$ & $\begin{array}{l}85.9 \% \\
87.8 \%\end{array}$ & & $\begin{array}{l}92.3 \% \\
94.8 \%\end{array}$ & \\
\hline
\end{tabular}




\begin{tabular}{|c|c|c|c|c|c|c|c|c|c|}
\hline & $\begin{array}{l}\text { Wast } \\
\text { e } \\
\text { (MSW } \\
\text { ), } \\
\text { Marke } \\
\text { t } \\
\text { Wast } \\
\text { e } \\
\text { (MW) } \\
\text { and } \\
\text { Flowe } \\
\text { r } \\
\text { Wast } \\
\text { e (FW }\end{array}$ & & $1: 3(\mathrm{c}: F W)$ & $87.5 \%$ & $80.9 \%$ & $85.5 \%$ & DN & $90.4 \%$ & $\begin{array}{l}\text { ( Swathi } \\
\text { Pattnaik } \\
\text { and } \\
\text { Vikram } \\
\text { Reddy, } \\
\text { 2009) }\end{array}$ \\
\hline $\begin{array}{l}\text { Perion } \\
y x \\
\text { excava } \\
\text { tus }\end{array}$ & 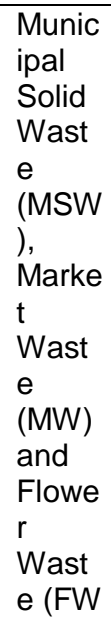 & 60 days & $\begin{array}{l}1: 3(\mathrm{c}: M S W) \\
1: 3(\mathrm{c}: M W) \\
1: 3(\mathrm{c}: F W)\end{array}$ & $\begin{array}{l}85.4 \% \\
78.1 \% \\
80.9 \%\end{array}$ & $\begin{array}{l}84.4 \% \\
82.1 \% \\
77.6 \%\end{array}$ & $\begin{array}{l}81.8 \% \\
81.5 \% \\
78.7 \%\end{array}$ & DN & $\begin{array}{l}90.7 \% \\
92.9 \% \\
85.9 \%\end{array}$ & $\begin{array}{l}\text { ( } \\
\text { Swathi } \\
\text { Pattnaik } \\
\text { and } \\
\text { Vikram } \\
\text { Reddy, } \\
\text { 2009) }\end{array}$ \\
\hline $\begin{array}{l}\text { E. } \\
\text { fetida } \\
\text { Savign } \\
\text { y } \\
\text { (Lumb } \\
\text { ercidea } \\
\text { ) }\end{array}$ & $\begin{array}{l}\text { Sewa } \\
\text { ge } \\
\text { Sludg } \\
\text { e } \\
\text { (SS) } \\
\text { and } \\
\text { Cow } \\
\text { Dung } \\
\text { (CD) }\end{array}$ & 12 weeks & $\begin{array}{l}\text { SS - } 10 \mathrm{~kg} \\
\mathrm{SS}+\mathrm{CD}-10+5 \\
\mathrm{~kg}\end{array}$ & DN & DN & $\begin{array}{l}19.2 \% \\
57.70 \%\end{array}$ & DN & $\begin{array}{l}19.2 \% \\
55.4 \%\end{array}$ & $\begin{array}{l}\text { ( Rajiv } \\
\text { et al., } \\
\text { 2009) }\end{array}$ \\
\hline $\begin{array}{l}\text { Eisenia } \\
\text { fetida }\end{array}$ & $\begin{array}{l}\text { Sewa } \\
\text { ge } \\
\text { Sludg } \\
\text { e } \\
\text { (SS), } \\
\text { cow } \\
\text { dung } \\
\text { (CD), } \\
\text { sheep } \\
\text { waste } \\
\text { (SW) } \\
\text { and } \\
\text { Garde } \\
\text { n soil } \\
\text { (GS) }\end{array}$ & 90 days & $\begin{array}{l}(2: 1) \\
S S \\
S S+C D \\
S S+S D \\
S S+G S\end{array}$ & DN & $\begin{array}{l}(\mathrm{mg} / \mathrm{kg}) \\
\\
242 \\
183 \\
182.3- \\
96 \\
171.7- \\
150.7 \\
204.3- \\
124.7\end{array}$ & DN & DN & DN & $\begin{array}{l}\text { ( } \\
\text { Hossein } \\
\text { Azarpira } \\
\text { et al., } \\
\text { 2014) }\end{array}$ \\
\hline $\begin{array}{l}\text { Eudrilu } \\
\text { s } \\
\text { eugeni } \\
\text { a }\end{array}$ & $\begin{array}{l}\text { Sewa } \\
\text { ge } \\
\text { Sludg } \\
\text { e } \\
\text { (SS), } \\
\text { cow } \\
\text { dung } \\
\text { (CD), } \\
\text { sheep }\end{array}$ & 90 days & $\begin{array}{l}(2: 1) \\
S S \\
S S+C D \\
S S+S D \\
S S+G S\end{array}$ & DN & $\begin{array}{l}(\mathrm{mg} / \mathrm{kg}) \\
242-175 \\
182.3- \\
107.7 \\
171.7-\end{array}$ & DN & DN & DN & $\begin{array}{l}\text { Hossein } \\
\text { Azarpira } \\
\text { et al., } \\
\text { 2014) }\end{array}$ \\
\hline
\end{tabular}




\begin{tabular}{|c|c|c|c|c|c|c|c|c|c|}
\hline & $\begin{array}{l}\text { waste } \\
\text { (SW) } \\
\text { and } \\
\text { Garde } \\
\mathrm{n} \text { soil } \\
\text { (GS) }\end{array}$ & & & & $\begin{array}{l}143.0 \\
204.3 \\
128.7\end{array}$ & & & & \\
\hline $\begin{array}{l}\text { Eisenia } \\
\text { fetida }\end{array}$ & $\begin{array}{l}\text { Cow } \\
\text { Dung } \\
\text { (CD) } \\
\text {,poultr } \\
\text { y } \\
\text { droppi } \\
\text { ng } \\
\text { (PD) } \\
\text { and } \\
\text { solid } \\
\text { Textil } \\
\text { e mill } \\
\text { Sludg } \\
\text { e } \\
\text { (STM } \\
\text { S) }\end{array}$ & 77 days & $\begin{array}{l}\text { CD+PD+STMS } \\
(\mathrm{g}) \\
0+105+45 \\
0+90+60 \\
0+75+75 \\
0+60+90 \\
0+45+105 \\
105+45+0 \\
45+105+0 \\
37.5+37.5+75 \\
150+0+0\end{array}$ & DN & $\begin{array}{l}(\mathrm{mg} / \mathrm{kg}) \\
280-200 \\
260-150 \\
320-200 \\
280-170 \\
390-180 \\
140-79 \\
289-190 \\
390-196 \\
283-176\end{array}$ & $\begin{array}{l}(\mathrm{mg} / \mathrm{kg}) \\
0.61-0.32 \\
0.69-0.27 \\
0.58-0.27 \\
0.63-0.36 \\
0.42-0.28 \\
0.40-0.26 \\
0.54-0.31 \\
0.47-0.29\end{array}$ & DN & $\begin{array}{l}(\mathrm{mg} / \mathrm{kg}) \\
0.82-0.62 \\
0.95-0.71 \\
0.83-0.60 \\
1.20-0.65 \\
0.83-0.52 \\
0.76-0.64 \\
0.98-0.73 \\
0.94-0.69 \\
1.21-0.73\end{array}$ & $\begin{array}{l} \\
\text { ( Hossein } \\
\text { Azarpira } \\
\text { et al., } \\
\text { 2014) }\end{array}$ \\
\hline
\end{tabular}

\section{CONCLUSIONS}

This review focuses on both the population of fungus and earthworm can be able to survive and even flourish in environments contaminated with heavy metals. It concluded that, by the knowledge of the mentioned studies, several species of fungus have been utilized as the effective tool in Mycoremediation. Studies have exposed that fungal species can bioaccumulate heavy metals from metal contaminants. During vermicomposting process, fungus can be utilized in the pre-composting process, it reduces the pre-composting period and toxicity to the earthworm. By the combination of Mycoremediation and vermiremediation, we will get the final bio-fertilizer as the end product in short period of time. Fungus and earthworm show capabilities for accumulating heavy metals and discharge the non-hazardous bio-fertilizer The end product comes from the vermicompost contains the enriched amount of NPK. This review seems to be highly promising in terms of the creation of platforms that encourage the development of bioremediation processes using fungus and earthworm.

\section{ACKNOWLEDGMENT}

The authors are very grateful to Coimbatore Institute of Technology, Coimbatore, Tamilnadu, India for sponsoring this study through the TEQIP-PHASE II is gratefully acknowledged.

\section{REFERENCES}

1. Adeyemi, A.O., 2009. Bioaccumulation of Arsenic by Fungi. Am. J. Environ. Sci. 5. 364-370.

2. Adi ainurzaman Jamaludin, Noor Zalina Mahmood. 2010. Effects of vermicomposting duration to macronutrient elements and heavy metals concentrations in vermicompost. Sains Malaysian. 39(5). 711-715.

3. Ahluwalia, S.S., Goyal. D., 2007. Microbial and plant derived biomass for removal of heavy metals from wastewater. Bioresour. Technol. 98. 2243-2257.

4. Ahmad, I., Ansari, I. and Aqil, F., 2005. Biosorption of Ni, $\mathrm{Cr}$ and $\mathrm{Cd}$ by metal tolerant Aspergillus niger and Penicillium sp. using single and multi-metal solution. Indian J. Exp. Biol., 44. 73-76.

5. Akar T, Tunali S., 2006. Biosorption characteristics of Aspergillus flavus biomass for removal of $\mathrm{Pb}$ (II) and $\mathrm{Cu}$ (II) ions from an aqueous solution. Bioresour Technol. 97(15), 1780-1787.

6. Akar, T., Tunali, S., Cabuk, 2007. A Study on the characterization of lead (II) biosorption by fungus Aspergillus parasiticus. Appl. Biochem. Biotechnol. 136. 389-406.

7. Akhtar, K., Akhtar, M.W. and Khalid, A.M. 2008. Removal and recovery of Zirconium from its aqueous solution by Candida tropicalis. J. Hazard. Mater. 156. 108-117.

8. Akhtar, M.N. and P.M. Mohan., 1995. Bioremediation of toxic metal ions from polluted lake-waters and industrial effluents by fungal biosorbent. Curr. Sci. 69(12). 1030-1038.

9. Amini, M., Younesi, H. and Bahramifar, N., 2009. Statistical modeling and optimization of the cadmium biosorption process in an aqueous solution using Aspergillus niger. Colloids Surf. Physicochem. Eng. Aspects. 337. 67-73.

10. Anaemene, I.A., 2012. The Use of Candida sp in the Biosorption of Heavy Metals from Industrial Effluent. Eur. J. Exp. Biol. 2. 484-488.

11. Anand, P., Isar, J., Saran, S., Saxena, R.K., 2006. Bioaccumulation of copper by Trichoderma viride. Bioresour. Technol. 97.1018-1025. 
12. Asgher, M., Bhatti, H.N., Ashraf, M., Legge, R.L., 2007. Recent developments in biodegradation of industrial pollutants by white-rot fungi and their enzyme system. Biodegradation. 19. 771-783.

13. Ashida, J., 1965. Adaptation of fungi to metal toxicants. Ann. Rev. Phytopathol. 3.153-174.

14. Ashok Kumar, Bisht, B.S., Joshi, V.D., 2011. Zinc and Cadmium removal by acclimated Aspergilus niger: Trained fungus for biosorption. International Journal of Environmental Sciences and Research. 1. 27-30.

15. Ausra Zigmontiene, Indre Liberyte. 2014. Heavy metals ( $\mathrm{Cr}, \mathrm{Cd}$, and $\mathrm{Ni}$ ) concentrations in sewage sludge and bioaccumulation by Californian Earthworms in process of vermicomposting. The $9^{\text {th }}$ international conference Environmental Engineering. Lithunia.

16. Bai, R.S., Abraham, T.E., 2003. Studies on chromium (VI) adsorption desorption using immobilized fungal biomass. Biores. Technol. 87 (1). 17-26.

17. Bai, S and Abraham., T.E., 2001. Biosorption of chromium (VI) from aqueous solution by Rhizopus nigricans. Bioresour. Technol. 79. 73-81.

18. Bajgai, R.C., Georgieva, N. and Lazarova, N., 2012. Bioremediation of chromium ions with filamentous yeast Trichosporon cutaneum R57. J. Biol. Earth Sci. 2. 70-75.

19. Baldrian, P., 2003. Interactions of heavy metals with white-rot fungi. Enzyme Microb Technol. 32. 78-91.

20. Benitez, E., Nogales, R., Elvira, C., Masciandaro, G., Ceccanti, B., 1999. Enzyme activites as indicators of the stabilization of sewage sludge composting with Eisenia fetida. Biresour. Technol. 67. 297-303.

21. Beveridge, T.J., Schultze-Lam, S., 1995. Detection of anionic sites on bacterial walls, their ability to bind toxic heavy metals and form sedimentable flocs and their contribution to mineralization", In: Allen, H.E., Huang, C.P., Bailey, G.W. (Eds), Metal speciation and contamination of soil. CRC Press, Boca raton, pp. 183-205.

22. Bishnoi, N.R., Kumar, R., Bishnoi, K., 2007. Biosorption of $\operatorname{Cr}(\mathrm{VI})$ with Trichoderma viride immobilized fungal biomass and cell free Caalginate beads. Indian. J. Exp. Biol. 45(7). 657- 664.

23. Brierley C.L., Brierley, J.A., 1993. Immobilization of Biomass for Industrial Application of Biosorption, In: Torma AE, Apel ML, Brierley CL, Warren dale PA, Biohyrometallurgy Technologies, the Minerals, Metals and Materials Society.

24. Bumpus, J.A., Tlon, M., Wright, D., Aust, S.D., 1985. Oxidation of persistent environmental pollutants by white rot fungus. Science. 228. 1434-1436.

25. Chandrakar, V., Verma, P. and Jamaluddin., 2012. Removal of cu and zn by fungi in municipal sewage water. Int. J. Adv. Biotechnol. Res. 2. 787-790.

26. Chaudhari, P.S., Bhattacharjee, G., 2002. Capacity of various experimental diets to support biomass and reproduction of Perionyx excavates. Biores. Technol. 82. 47-150.

27. Chen G, Zeng G, Tang L, Du C, Jiang X, Huang G, Liu H, Shen G. 2008. Cadmium removal from simulated wastewater to biomass byproduct of Lentinus edodes. Bioresour Technol., 99(15), 7034-7040.

28. Congeevaram, S., Dhanarani, S., Park, J., Dexilin, M. and Thamaraiselvi, K., 2007. Biosorption of chromium and nickel by heavy metal resistant fungal and bacterial isolates. J. Hazard. Mater. 146, 270-277.

29. Kabata-Pendias and H. Pendias, 2001. Trace Metals in Soils and Plants, CRC Press, Boca Raton, Fla, USA, 2nd edition.

30. G. M. Pierzynski, J. T. Sims, and G. F. Vance, 2000. Soils and Environmental Quality", CRC Press, London,UK, 2nd edition.

31. S. Kuo, P. E. Heilman, and A. S. Baker, 1983. Distribution and forms of copper, zinc, cadmium, iron, and manganese in soils near a copper smelter. Soil Science. 135(2). 101- 109.

32. M. Kaasalainen and M. Yli-Halla, 2003. Use of sequential extraction to assess metal partitioning in soils. Environmental Pollution. 126(2). 225-233.

33. S. Khan, Q. Cao, Y. M. Zheng, Y. Z. Huang, and Y. G. Zhu, 2008. Health risks of heavy metals in contaminated soils and food crops irrigated with wastewater in Beijing, China. Environmental Pollution. 152(3). 686-692.

34. M. K. Zhang, Z. Y. Liu, and H.Wang, 2010. Use of single extraction methods to predict bioavailability of heavy metals in polluted soils to rice. Communications in Soil Science and Plant Analysis. 41(7). 820-831.

35. N. T. Basta, J. A. Ryan, and R. L. Chaney, 2005. Trace element chemistry in residual-treated soil: key concepts and metal bioavailability. Journal of Environmental Quality. 34(1). 49-63, 2005.

36. Scragg, 2006. Environmental Biotechnology. Oxford University Press, Oxford, UK, 2nd edition.

37. P. Loganathan, M.J. Hedley, N.D. Grace, 2008. Pasture soils contaminated with fertilizer derived cadmium and fluoride: livestock effects. Rev. Environ. Contam. Toxicol. 192. 29-66.

38. N.S. Bolan, D.C. Adriano, R. Naidu, 2003. Role of phosphorus in immobilization and bioavailability of heavy metals in the soil-plant system. Rev. Environ. Contam. Toxicol. 177. 1-44.

39. R.A. Wuana, F.E. Okieimen, 2011. Heavy metals in contaminated soils: a review of sources, chemistry, risks and best available strategies for remediation. ISRN Ecol. 1-20.

40. L. H. P. Jones and S. C. Jarvis, 1981. The fate of heavy metals. The Chemistry of Soil Processes, D. J. Green and M. H. B. Hayes, Eds., JohnWiley \& Sons, New York, NY, USA. 593.

41. N.S. Bolan, M.A. Khan, J. Donaldson, D.C. Adriano, C. Matthew, 2003. Distribution and bioavailability of copper in farm effluent. Sci. Total Environ. 309. 225-236. 
42. A.M. Wightwick, S.A. Salzman, S.M. Reichman, G. Allinson, N.W. Menzies, 2013. Effects of copper fungicide residues on the microbial function of vineyard soils. Environ. Sci. Pollut. Res. 20. 1574-1585.

43. E. Chopin, B. Marin, R. Mkoungafoko, A. Rigaux, M. Hopgood, E. Delannoy, B. Cances, M. Laurain, 2008. Factors affecting distribution and mobility of trace elements ( $\mathrm{Cu}, \mathrm{Pb} \mathrm{Zn}$ ) in a perennial grapevine (Vitis vinifera $\mathrm{L}$.) in the Champagne region of France. Environ. Pollut. 156, 1092-1098.

44. D.A. Heemsbergen, M.J. McLaughlin, M. Whatmuff, M.S.J. Warne, K. Broos, M.J. Bell, D. Nash, G. Barry, D. Pritchard, N. Penney, 2010. Bioavailability of zinc and copper in biosolids compared to their soluble salts. Environ. Pollut.158. 1907-1915.

45. Hildebrandt, M. Guillamon, S. Lacorte, R. Tauler, D. Barcelo, 2008. Impact of pesticides used in agriculture and vineyards to surface and groundwater quality (North Spain). Water Res. 42. 3315-3326.

46. A.M. Wightwick, S.A. Salzman, S.M. Reichman, G. Allinson, N.W. Menzies, 2010. Inter-regional variability in environmental availability of fungicide derived copper in vineyard soils: an Australian case study. J. Agric. Food Chem. 58. 449-457.

47. M. van Zwieten, G. Stovold, L. van Zwieten, 2007. Alternatives to copper for disease control in the Australian organic industry, A report for the Rural Industries Research and Development Corporation. RIRDC Publication No $07 / 110$.

48. X. Zhou, Z.L. He, Z.B. Liang, P.J. Stoffella, J. Fan, Y.G. Yang, C.A. Powell, 2011. Long term use of coppercontaining fungicide affects microbial properties of citrus grove soils. Soil Sci. Soc. Am. J., 75, 898-906.

49. P. S. DeVolder, S. L. Brown, D. Hesterberg, and K. Pandya, 2003. Metal bioavailability and speciation in a wetland tailings repository amended with bio-solids compost, wood ash, and sulfate. Journal of Environmental Quality. 32(3). 851-864.

50. M. E. Sumner, 2000. Beneficial use of effluents, wastes, and biosolids. Communications in Soil Science and Plant Analysis. 31(11). 1701-1715.

51. USEPA, 1996. Report: recent Developments for In Situ Treatment of Metals contaminated Soils. U.S. Environmental Protection Agency, Office of Solid Waste and Emergency Response.

52. J. Shiowatana, R. G. McLaren, N. Chanmekha, and A. Samphao, (2001). Fractionation of arsenic in soil by a continuous flow sequential extraction method. Journal of Environmental Quality.30(6). 1940-1949.

53. J. Buekers, 2007. Fixation of cadmium, copper, nickel and zinc in soil: kinetics, mechanisms and its effect on metal bioavailability.Ph.D. thesis, Katholieke Universiteit Lueven, Dissertationes De Agricultura, Doctoraatsprooefschrift nr.

54. USDHHS, 1999. Toxicological profile for lead. United States Department of Health and Human Services, Atlanta, Ga, USA.

55. NSC, Lead Poisoning, National Safety Council, 2009, http:// www.nsc.org/news resources/Resources/Documents/Lead Poisoning.pdf.

56. D. R. Baldwin and W. J. Marshall, 1999. Heavy metal poisoning and its laboratory investigation. Annals of Clinical Biochemistry. 36(3). 267-300.

57. L. A. Smith, J. L. Means, A. Chen., 1995. Remedial Options for Metals-Contaminated Sites. Lewis Publishers, Boca Raton, Fla, USA.

58. Beleza, V.M., Boaventura, R.A., Almeida, M.F., 2001. Kinetics of chromium removal from spent tanning liquors using acetylene production sludge. Environmental Science and Technology. 35. 4379-4383.

59. Czako-Ver, K., Batic, M., Raspor, P., Sipicki, M., Pesti, M., 1999. Hexavalent chromium uptake by sensitive and tolerant mutants of Schizosacchoromyces pombe. FEMS Microbiology Letters. 178. 109-115.

60. B. E. Davies and L. H. P. Jones, 1988. Micronutrients and toxic elements in Russell's Soil Conditions and Plant Growth, A. Wild, Ed., JohnWiley \& Sons; Interscience, New York, NY, USA, 11th edition. 781-814.

61. P. G. C. Campbell, 2006. Cadmium-A priority pollutant. Environmental Chemistry. 3(6). 387-388.

62. K. Weggler, M. J. McLaughlin, and R. D. Graham, 2004. Effect of Chloride in Soil Solution on the Plant Availability of Biosolid-Borne Cadmium. Journal of Environmental Quality. 33(2). 496-504.

63. S.E. Manahan, 2003. Toxicological Chemistry and Biochemistry. CRC Press, Limited Liability Company (LLC), 3rd edition.

64. CPCB. 2009. National inventory of hazardous waste generating industries \& hazardous waste management system in India. http://www.indiaenvironmentportal.org.in/files/hazardous-waste inventory final report 2009.pdf. Accessed 22 july 2009.

65. Damodaran, D., Gummadi, S. and RajMohan, B., 2011. Bioremediation of soil by removing heavy metals using Saccharomyces cerevisiae. 2nd International Conference on Environmental Science and Technology IPCBEE. 6 , IACSIT Press, Singapore.

66. Delgado, A., Anselmo, A.M., Novais, J.M., (1998). Heavy metal biosorption by dried powdered mycelium of Fusarium flocciferum. Water. Environ. Res. 70. 370-375.

67. Dugal, S. and Gangawane, M., (2012). Metal tolerance and potential of Penicillium species for use in Mycoremediation. J. Chem. Pharm. Res. 4. 2362-2366.

68. Elander, R.P., Neway, O., 1989. Bioprocess technology in industrial fungi. In: Fermentation process Development of Industrial Organisms. Ed, Marcel Dekker, New York. 169 -219. 
69. El-Gendy, M.M.A., Hassanein, N.M., El-Hay I.H., El-Baky, A. and Doaa, H., 2011. Evaluation of some fungal endophytes of plant potentiality as low-cost adsorbents for heavy metals uptake from aqueous solution. Aust. J. Basic Appl. Sci. 5. 466- 473.

70. Elvira, C., Goicoechea, M., Sampdro, L., Mato, S., Nogales, R., 1996. Bioconversion of solid paper-pulp mill sludge by earthworms. Biores. Technol. 75. 173-177.

71. Elvira, C., Sampedro, L., Benitez, E., Nogales, R., 1998. Vermicomposting of sludge from paper mill and dairy industries with Eisenia Andrei: a pilot scale study. Biores. Technol. 63. 205-211.

72. Fan, T., Liu, Y., Feng, B., Zeng, G., Yang, C., Zhou, M., Zhou, H., Tan, Z. and Wang, X., 2008. Biosorption of cadmium (II), zinc (II) and lead (II) by Penicillium simplicissimum: Isotherms, kinetics and thermodynamics. J. Hazard. Mater. 160. 655-661.

73. Faryal, R., Sultan, A., Tahir, F., Ahmed, S. and Hameed, A., 2007. Biosorption of lead by indigenous fungal strains. Pak. J. Bot. 39. 615-622.

74. Fourest, E., Canal, C., and Roux, J.C., 1994. Improvement of heavy metal biosorption by mycelia dead biomass (Rhizopus arrhizus, Mucor miehei and Penicillium chrysogemum): $\mathrm{pH}$ control and cation activation. FEMS Microbiol. Review. 14. 325-332.

75. Gadd, G.M. and de Rome, L., 1988. Biosorption of copper by fungal melanine. Appl. Microbiol. Biotechnol. 29. 610-617.

76. Gadd, G.M., 1986. Fungal responses towards heavy metals. In: Herbert RA, Codd GA, Microbes in Extreme Environments. Academic Press, London.

77. Gadd, G.M., 1990. Heavy metal accumulation by bacteria and other microorganisms. J. Ann. Experi. 46, 834840 .

78. Gadd, G.M., 1992. Molecular biology and biotechnology of microbial interaction with organic and inorganic heavy metal compounds. In: Herbert, R.A., Sharp, R.J. (Eds.), Molecular Biology and Biotechnology of Extreamophiles. Blackie and Sons, Glasgow, pp.225-257.

79. Gadd, G.M., 1993. Interaction of fungi with toxic metals. New. Phytol. 12. 25-60.

80. Gadd, G.M., 1996. Role of microorganisms in the environmental fate of radionuclides. Endeavour. 20. 150-156.

81. Gadd., G.M., 1990, Fungi and yeast metal accumulation. In: Ehrlich, H.L., Brierley, C.L. (Eds.), Microbiol Mineral Recovery. McGraw-Hill, New York. pp. 249-276.

82. Galun, M., Galun, E., Siegel, B.Z., Keller, P., Lehr, H. and Siegel, S.M., 1987. Removal of metal ions from aqueous solutions by Penicillium biomass: kinetic and uptake parameters. Water Air Soil Pollut. 33. 359-371.

83. Garg, V.K., Kaushik, P., 2005. Vermistabilization of textile mill sludge spiked with poultry droppings by an epigeic earthworm Eisenia fetida. Bioresour. Technol. 96. 1063-1071.

84. Ghosh, M., Chattopadhyay G.N., Baral, K., 1999. Transformation of phosphorus during vermicomposting. Biores Technol. 69. 149- 154.

85. Ghyasvand, S., Alikhani, H.A., Ardalan, M.M., Savaghebi, G.R., Hatami, S., 2008. Effect of pre-thermo composting on decrease of cadmium and lead pollution in vermicomposting of municipal solid waste by Eisenia fetida. American Eurasian J. Agric Environ Sci. 4(5). 537-540.

86. Guang Ming Zeng, DanLian Huang, GuoHe Huang, TianJue Hu, XiaoYun Jiang, ChongLing Feng, YaoNing Chen, Lin Tang, HongLiang Liu. 2007. Composting of lead-contaminated solid waste with inocula of white-rot fungus. Bioresource Technology. 98. 320-326.

87. Gunadi, B., Blount, C., Edward, C.A., 2002. The growth and fecundity of Eisenia foetida (savigny) in cattle solids pre-composted for different periods. Pedobiologia. 46.15-23.

88. Gunadi, B., Edwards, C.A., (2003). The effect of multiple applications of different organic wastes on the growth, fecundity and survival of Eisenia foetida (Savigny) (Lumbricidae). Pedobiologia. 47 (4). 321 - 330.

89. Gunasekaran, P., Muthukrishnan, J., Rajendran, P., 2003. Microbes in Heavy Metal Remediation. Indian Journal of Experimental Biology. 4. 935-944.

90. Hait, S., Tare, V., 2011. Vermistabilization of primary sewage sludge. Bioresour. Technol. 102. 2812-2820.

91. Hala, Y.E.K. and Eman, M.E.T., 2009. Optimization of batch process parameters by response surface methodology for mycoremediation of chrome-VI by a chromium resistant strain of marine Trichoderma Viride. Am. Eurasian J. Agric. \& Environ. Sci. 5. 676-681.

92. Haritash, A.K., Kaushik, C.P., 2009. Biodegradation aspects of polycyclic aromatic hydrocarbons (PAHs): A review. J. Haz. Mat. 169.1-15.

93. Harms, H., Schlosser, D., Wick, L.Y., 2011. Untapped potential: exploiting fungi in bioremediation of hazardous chemicals. Nat Rev Microbiol. 9. 177-192. 
94. Hartenstein, R., Hartenstein, F., 1981. Physicochemical changes affected in activated sludge by the earthworm Eisenia fetida. J. Environ. Qual. 10.372-376.

95. Hossein Azarpira, Pejman Behdarvand, Kondriram Dhumal and Gorakh pondhe, 2014. Vermiremoval of macroelements and heavymetals in Municipal sewage sludge. Journal of applied science and agriculture. 9(1). 50-55.

96. Huang D, Zeng G, Feng, C, Hu S, Jiang X, Tang L, Su F, Zhang Y, Zeng, W, Liu H., 2008. Lead-contaminated lignocellulosic waste by Phanerochaete chrysosporium and the reduction of lead toxicity. Environ Sci Technol. 42(13). 4946-4951.

97. Huang, C.P., Huang, C.P. and Morehart, A.L., 1990. Removal of copper (II) from dilute aqueous solutions by Saccharomyces cerevisiae. Water Res. 24. 433-439.

98. Huang, D.L., Zeng, G.M., Hu, T.J., Huang, G.H., 2003. Preliminary study on the application of Phanerochaete chrysosporium in composting of lignin waste. in: Proceedings of Ener. Env. Conference. Changsha. China. 907912.

99. Huang, D.L., Zeng, G.M., Jiang, X.Y., Feng, C. L.,Yu, H.Y., Huang, G.H., and Liu, H.L., 2006. Bioremediation of $\mathrm{Pb}$-contaminated soil by incubating with Phanerochaete chrysosporium and straw. J. Hazard. Mater. 134. 268276.

100. Hussein, H., Farag. S., Moawad, H., 2004. Isolation and characterization of Pseudomonas resistant to heavy metals contaminants. Arab. J. Biotechnol. 7. 13-22.

101. Ianis, M., Tsekova, K. and Vasileva, S., 2006. Copper biosorption by Penicillium cyclopium: equilibrium and modelling study. Biotech. Bioeng. 20. 195-201.

102. Ismail, K., Akar, T. and Tunali, S., 2005. biosorption of $\mathrm{Pb}$ and $\mathrm{Cu}$ from aqueous solution by pretreated biomass of Neurospora crassa. Proc. Biochem. 40. 3550-3558.

103. Izadpanah, M., Sarrafi, R., Fazaelipoor, A. and Mosalmanzadeh, M.H., 2009. Investigation on the biological leaching of copper from chalcopyrite concentrates using moderate thermophilic bacteria. Sci. Iran. Trans. C Chem. Chem. Eng. 16(1), 54-60.

104. Joshi, P.K., Swarup, A., Maheshwari, S., Kumar, R. and Singh, N., 2011. Bioremediation of heavy metals in liquid media through fungi isolated from contaminated sources. Indian J. microbial. vol. 51. 482-487.

105. Junior, L.M.B., Macedo, G.R., Duarte, M.M.L., Silva, E.P. and Lobato, A.K.C.L., 2003. Biosorption of cadmium using the fungus Aspergillus niger. Braz. J. Chem. Eng. 20. 229-239.

106. Kabata-Pendias, A and Pendias, H., 2001. Trace Metals in Soils and Plants. CRC Press, Boca Raton, Fla, USA, 2nd edition.

107. Kapoor, A., Viraraghavan, T., 1998. Biosorption of heavy-metal on Aspergillus niger: effect of pretreatment. Biores. Technol. 63. 109-113.

108. Kapoor, A., Viraraghavan, T., Cullimore, D.R., 1999. Removal of heavy metals using fungus Aspergillus niger. Biores. Technol. 70. 95-104.

109. Kaur, A., Singh, J., Vig, A.P., Dhaliwal, S.S., Rup, P.J., 2010. Cocomposting with and without Eisenia fetida for conversion of toxic paper mill sludge into soil conditioner. Bioresour. Technol. 101. 8192-8198.

110. Kelly, D.J.A., Budd, K., Lefebvre D.D., 2006. The biotransformation of mercury in pH-stat cultures of microfungi. Can J Bot., 84(2). 254-260.

111. Khan et al., 1998. Investigation of fungi as biosorbents for removal of metal ions from waste water. WISA Biennial conference. Cape Town.

112. Khan, A.G., 2001. Relationship between chromium biomagnifications ratio accumulation factor and mycorrhizal in plants growing on tannery effluent polluted soils", J. Environ. International, vol. 26, 417-423.

113. Kiran, I., Akar, T., Tunali, S., 2005. Biosorption of $\mathrm{Pb}(\mathrm{II})$ and $\mathrm{Cu}$ (II) from aqueous solutions by pretreated biomass of Neurospora crassa. Process Biochem. 40(11). 3550-3558.

114. Kumar, A., Bisht, B.S. and Joshi, V.D., 2011. Zinc and Cadmium removal by acclimated Aspergilus niger: Trained fungus for biosorption. Int. J. Environ. Sci. Res., 1, 27-30.

115. Levinskaite, L., 2001. Simultaneous effect of Ni, Cd and $\mathrm{Cr}$ on soil micromycetes, Biologija,13-15.

116. Li, Q.B., Wu, S.T., Liu, G., Liao, X.K., Deng, X., Sun, D.H., Hu, Y.L., Huang, Y.L., 2004. Simultaneous biosorption of cadmium(II) and lead(II) ions by pretreated biomass of Phanerochaete chrysosporium. Sep. Purif. Technol. 34 135-142.

117. López Errasquín, E., Vázquez, C., 2003. Tolerance and uptake of heavy metals by Trichoderma atroviride isolated from sludge. Chemosphere. 50. 137-143.

118. Magyarosy, A., Laidlaw, R.D., Kilaas, R., Echer, C., Clark, D.S, Keasling, J.D., 2002. Nickel accumulation and nickel oxalate precipitation by Aspergillus niger. Appl. Microbiol. Biotechnol. 59. 382-388.

119. Maheswari, S. and Murugesan, A.G., 2009. Remediation of arsenic in soil by Aspergillus nidulans isolated from an arsenic-contaminated site. Environ. Technol. 30. 921- 926. 
120. Majumdar, D., Patel, J., Bhatt, N., Desai, P., 2006. Emission of methane and carbon dioxide and earthworm survival during composting of pharmaceutical sludge and spent mycelia. Bioresource Technol., 97. 648-658.

121. Mehra, R.K., Winge, D.R., 1991. Metal ion resistance in fungi. Molecular mechanism and their related expression. J. Cellular. Biochem. 45. 30-40.

122. Munoz, R., Alvarez, M.T., Munoz, A., Terrazas, E., Guieysse, B., Mattisasson, B., 2006. Sequential removal of heavy metals ions and organic pollutants using an algal-bacterial consortium. Chemosphere. 63. 903-991.

123. Munoz, R., Guieysse, B., 2006. Algal-bacterial processes for the treatment of hazardous contaminants: a review. Water. Res. 40. 2799-2815.

124. Nahmani, J., Hodson, M.E., Black, s., 2007. A review of studies performed to assess metal uptake by earthworm. Environmental. Pollution. 145. 402 - 424.

125. Nasseri, S., Mazaheri, A.M., Noori, S.M., Rostami, K.H., Shariat, M. and Nadafi, K., 2002. Chromium removal from tanning effluent using biomass of Aspergillus oryzae. Pak. J. Biol. Sci. 5. 1056-1059.

126. Ndegwa, P.M., Thompson, S.A., 2001. Integrating composting and vermicomposting the treatment and bioconversion of biosolids. Biores. Technol.76. 107-112.

127. Neuhauser, E.F., Loehr, R.C., Malecki, M.R., 1988. The potential of earthworms for managing sewage sludge. In: Edwards, C.A., Neuhauser, E.F. (Eds.), Earthworms in Waste and Environmental Management. SPB Academic Publishing, The Hague. 9-20.

128. Niu, H., Xu, X.S., Wang, J.H. and Volesky, B., 1993. Removal of lead from aqueous solutions by Penicillium biomass. Biotechnol. Bioeng. 42. 785-787.

129. Pal, T.K., Bhattacharyya, S. and Basumajumdar, A., 2010. cellular distribution of bioaccumulated toxic heavy metals in Aspergillus niger and Rhizopus arrhizus. Int. J. Pharma. Bio. Sci. 1. 1-6.

130. Parle, J.N., 1963. Micro organisms in the intestine of earthworms. J. Gen. Microbiol. 31. 1-11.

131. Pattanapipitpaisal, P., Brown, N.L. and Macaskie, L.E., 2001. Chromate reduction by Microbacterium liquefaciens immobilized in polyvinyl alcohol. Biotechnol. Lett. 23. 41-43.

132. Pereira, M.G., Arruda, M.A.Z., 2003. Vermicompost as a natural adsorbent material: characterization and potentialities for cadmium adsorption. J. Braz. Chem. Society., 14. 39-47.

133. Pierzynski, G.M., Sims, J.T., and Vance, G.F., 2000. Soils and Environmental Quality. CRC Press, London,UK 2nd edition.

134. Potin, O., C. Rafin and E. Veiguie., 2004. Bioremediation of an aged polycyclic aromatic hydrocarbon (PAHs) contaminated soil by filamentous fungi isolated from the soil international. Biodeterio Biodegrad., 54(1), 45-52.

135. Prakasham, R.S., Merrie, S., Sheela, J., Saswathi, N. and Ramakrishna, S.V., 1998. Biosorption of chromium (VI) by free and immobilized Rhizopus arrhizus. Environ. pollut., 104, 421-427.

136. Prasad, A.S., Varatharaju, G., Anushri, C. and Dhivyasree, S., 2013. Biosorption of Lead by Pleurotus florida and Trichoderma viride. Brit. Biotechnol. J. 3. 66-78.

137. Prasenjit, B. and Sumathi, S., 2005. Uptake of chromium by Aspergillus foetidus. J. Mater. Cycles Waste Manage, 7, 88-92.

138. Price, M.S., Classen, J.J., Payne, G.A., 2001. Aspergillus niger absorbs copper and zinc from swine wastewater. Bioresour. Technol. 77. 41-49.

139. Priya Kaushik, VK Garg., 2003. Vermicomposting of mixed solid textile mill sludge and cow dung with the epigeic earthworm Eisenia fetida. Bioresource Technology. 9(3). 311-316.

140. Qazilbash, A.A., 2004. Isolation and Characterization of Heavy Metal Tolerant Biota from Industrially Polluted Soils and Their Role in Bioremediation. Biological. Sci. 41. 210-256.

141. Rajiv K Sinha, Sunil Heart, Gokul Bharambe, Ashish Brahambhatt. 2009. Vermistabilization of sewage sludge (biosolids) by earthworm: converting a potential biohazard destined for landfill disposal into a pathogen-free, nutritive and safe biofertilizer for farms. Griffith School of Engineering (Environment), Griffith University, Australia.

142. Rajiv singh and Das S.C., 2005. Vermicomposting: An excellent way to recycle forest waste. Proceedings of National conference of Frontiers in Environmental Sciences and Engineering in India. Department of Env.Sc. Bharathiar University. Coimbatore. India. 75.

143. Ramasamy, R.K., Congeevaram, S. and Thamaraiselvi, K., 2011. Evaluation of isolated fungal strain from ewaste recycling facility for effective sorption of toxic heavy metal pb (II) ions and fungal protein molecular characterization- a mycoremediation approach. Asian J. Exp. Biol. Sci., vol. 2, pp. 342-247.

144. Ramesh, M., Subramanian, K., Kishore kumar, P., 2014. Fungal Biosorption of Heavy Metals from Industrial Waste. Asian Journal of Medical and Pharmaceutical Sciences. 2(2). 179-183.

145. Rao, C.R.N., lyengar, L. and Venkobachar, C., 1993. Sorption of Copper from aqueous phase by waste biomass. J. Environ. Eng. 119. 369-377.

146. Rao, K.R., Rashmi, K., Latha, J.N.L. and Maruthi, M.P., 2005. Bioremediation of toxic metal ions using biomass of Aspergillus fumigatus from fermentative waste. Indian J. Biotechnol. 4.139-143.

147. Ravindran, B., Dinesh, S.L., Kennedy, L.J., Sekaran, G., 2008. Vermicomposting of solid waste generated from leather industries using epigeic earthworm Eisenia fetida. Appl. Biochem Biotechnol. 151. 480-488.

148. Ravindran, R., Sekaran, G., 2011. Bacterial composting of animal fleshing generated from tannery industries. Waste Manage. 30. 2622-2630.

149. Remacle, J., 1990. The cell wall and heavy metals. In: Volesky B, Biosorption of Heavy Metals. CRC Press, Boca Raton, Florida.

150. Romero, M.C., Reinoso, E.H., Urrutia, M.I. and Kiernan, A.M., 2006. Biosorption of heavy metals by Talaromyces helicus: a trained fungus for copper and biphenyl detoxification. Electron. J. Biotechnol. 9. 221-226. 
151. Ross, I.S., 1975. Some effects of heavy metals on fungal cells. Trans. Br. Mycol. Soc. 64. 175-193.

152. Salem, H.M., Eweida, E.A., and Farag, A., 2000. Heavy metals in drinking water and their environmental impact on human health", In ICEHM 2000, Cairo University: Giza, Egypt, 542-556.

153. Sarkar, S., Satheshkumar, A., Jayanthi, R. and Premkumar, R., 2010. Biosorption of Nickel by live biomass of Trichoderma harzianum. Res. J. Agr. Sci. 1. 69-74.

154. Say, R., Yilmaz, N. and Denizli, A., 2003. Removal of heavy metal ions using the fungus Penicillium canescens. Adsorpt. Sci. Technol. 21. 643-650.

155. Seema Dwivedi, Anuradha Mishra, Devendra Saini. 2012, "Removal of Heavy Metals in Liquid Media through Fungi Isolated from Waste Water", International Journal of Science and Research, 1, 181-185.

156. Sen, B., Chandra, T.S., 2007. Chemolytic and solid-state spectroscopic evaluation of organic matter transformation during vermicomposting of sugar industry wastes. Bioresour. Technol. 98, 1680-1683.

157. Sen, M. and Dastidar, M.G., 2007. Biosorption of $\mathrm{Cr}(\mathrm{VI})$ by resting cells of Aspergillus sp. Iran. J. Environ. Health Sci. Eng. 4. 9-12.

158. Sen, M. and Dastidar, M.G., 2010. Adsorption desorption studies on $\mathrm{Cr}(\mathrm{VI})$ using nonliving fungal biomass. Asian J. chem., 22. 2331-2338.

159. Seshikala, D. and Charya, M.A.S., 2012. Effect of pH on Chromium biosorption. Int. J. Pharma. Bio.Sci. 2. 298302.

160. Shaheen Zafar, Farrukh Aqil, lqbal Ahmad. 2007. Metal tolerance and biosorption potential of filamentous fungi isolated from metal contaminated agricultural soil. Bioresource Technology, 98. 2557-2561.

161. Shahmansouri, M.R., Pourmoghadas, H., Parvaresh, A.R., Alidadi, H., 2005. Heavy Metals Bioaccumulation by Iranian and Australian Earthworms (Eisenia fetida) in the Sewage Sludge Vermicomposting. Iranian. J. Env. Health Sci. Eng. 2 (1). 28-32.

162. Shankar Congeevaram, Sridevi Dhanarani, Joonhong Park, Michael Dexilin, Kaliannan Thamaraiselvi. 2007. Biosorption of chromium and nickel by heavy metal resistant fungal and bacterial isolates. Journal of Hazardous Materials. 146. 270-277.

163. Shoaib, A., Aslam, N. and Aslam, N., 2012. Myco and Phyto Remediation of Heavy metals from aqueous solution. Onl. J. Sci. Technol. 2. 35-40.

164. Siddiquee, S., Aishah, S.N., Azad, S.A., Shafawati, S.N., Naher, L., 2013. Tolerance and Biosorption capacity of $\mathrm{Zn}^{2+}, \mathrm{Pb}^{2+}, \mathrm{Ni}^{3+}$ and $\mathrm{Cu}^{2+}$ by filamentous fungi (Trichoderma harzianum, T. aureoviride and T. virens). Adv. Biosci. Biotechnol. 4. 570-583.

165. Singh, J., Kaur, A., Vig, A.P., Rup, P.J., 2008. Role of Eisenia fetida in rapid recycling of nutrients from bio sludge of beverage industry. Ecotoxicol. Environ. Saf. 73. 430-435.

166. Skowronski, T., Pirszel, J. and Pawlik-Skwronska, B., 2001. Heavy metal removal by the waste biomass of Penicillium chrysogenum. Water Pollut. Res. J. Can., 36, 793-803.

167. Spugeon, D.J and Hopkin, S.P., 1999a. Comparisons of metal accumulation and excretion kinetics in earthworms (Eisenia fetida) exposed to contaminated field and laboratory soils. Appl. Soil. Ecol., 11/3. 227-243.

168. Sulata Maity, Sonali Roy, Shelley Bhattacharya and Shibani Chaudhury. 2010. Accumulation of lead and zinc in earthworm Lampito Mauritii (Kinberg): Effect on survival, growth and Acetycholinesterase activity. Recent Research in Science and Technology. 2(4). 46-53.

169. Surindra Suthar, N., Poonam Sajwan, Kapil Kumar. 2014. Vermiremediation of heavy metals in wastewater sludge from paper and pulp industry using earthworm Eisenia fetida. Ecotoxicol. Environ. Saf. 109. 177-184.

170. Suthar, S., 2006. Potential utilization of guar gum industrial waste in vermicompost production. Bioresour. Technol. 97. 2474-2477.

171. Suthar, S., 2010. Recycling of agro-industrial sludge through vermitechnology. Ecol. Eng. 36. 1028-1036.

172. Suthar, S., Singh, S., 2008. Feasibility of vermicomposting in bio-stabilization of sludge from a distillery industry. Sci. Total. Environ. 394. 237-243.

173. Swathi Pattnaik and M. Vikram Reddy. 2009. Nutrient status of vermicompost of urban green waste processed by three earthworm species- Eisenia fetida, Eudrilus eugeniae and perionyx excavates. Applied and Environmental soil science. 2010,1-13.

174. Tahir, A., 2012. Resistant fungal biodiversity of electroplating effluent and their metal tolerance index. (Ed) $D$ Sebayang, ISBN: 978-953-51-0471-1, Available from: http://www.intechopen.com

175. Tan, T. and Cheng, P., 2003. Biosorption of metal ions with Penicillium chrysogenum. Appl. Biochem. Biotechnol. 104. $119-128$

176. Terres, E., Cid, A., Herrero, C., Abalde, J., 1998. Removal of cadmium ions by the marine diatom Phaeodactylum tricornutum Bohlin accumulation and long-term kinetics of uptake. Biores. Technol. 63. 213-220.

177. Teskova, K. and G. Petrov., 2004. Removal of heavy metals from aqueous solution using Rhizopus delemar mycelia in free and polyurethane- bound form Zeits fur Natur for schung, vol. 57(7-8), 629-633.

178. Thippeswamy, B., Shivakumar, C.K. and Krishnappa, M., 2012b. Accumulation potency of heavy metals by saccharomyces sp. indigenous to paper mill effluent. J. Environ. Res. Dev. 6. 439-445.

179. Thippeswamy, B., Shivkumar, C.K. and Krishnappa, M., 2012. Bioaccumulation potential of Aspergillus niger and Aspergillus flavus for removal of heavy metals from paper mill effluent. J. Environ. Biol., 33, 1063-1068.

180. Townsley, C.C. and Ross, I.S., 1985. Copper uptake by Penicillium spinulosum. Microbes. 44. 125-134. 


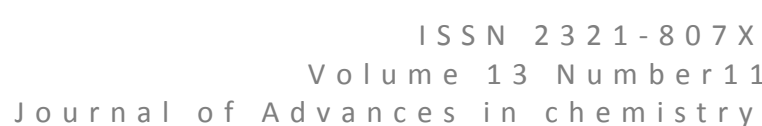

181. Toyota, K., Kirmura, M., 2000. Microbial community indegious to the earthworm Eisenia fetida. Biol. Fert. Soils. 31. 187-190.

182. Tsezos, M. and Volesky, B., 1981. Biosorption of uranium and thorium. Biotechnol Bioeng. 23. 583-604.

183. Tunali, S., Akar, T., 2006. Zn (II) biosorption properties of Botrytis cinerea biomass. J Hazard Mater. 131(1-3). $137-145$.

184. Tunali, S., Akar, T., Oezcan, A.S., Kiran, I., Oezcan. 2006. A Equilibrium and kinetics of biosorption of lead(II) from aqueous solutions by Cephalosporium aphidicola. Sep", Purif Technol. 47(3). 105-112.

185. Valls, M., de Lorenzo, V., 2002. Exploiting the genetic and biochemical capacities of bacteria for the remediation of heavy metal pollution. FEMS Microbiol Rev., 26. 327-338.

186. Vankar, P.S. and Bajpai, D., 2007. Phyto-remediation of chrome-VI of tannery effluent by Trichoderma species. Presented at the conference on Desalination and the Environment. Sponsored by the European Desalination Society and Center for Research and Technology Hellas (CERTH), Sani Resort, Halkidiki, Greece. pp 22-25.

187. Varshney, R., Bhadauria, S. and Gaur, M.S., 2010. Biosorption of Copper (II) from electroplating wastewaters by Aspergillus terreus and its kinetics studies. Water. 2. 142-151.

188. Velmurugan, N., Hwang, G., Muthuswamy, S.K., Choi, T.K., Kui-Jae, L., Byung-Taek, O. and Yang-Soo, L., 2010. Isolation, identification, $\mathrm{Pb}$ (II) biosorption isotherms and kinetics of a lead adsorbing Penicillium sp. MRF-1 from South Korean mine soil. J. Environ. Sci. 22. 1049-1056.

189. Venkobacher, C., 1990. Metal removal by waste biomass to upgrade wastewater treatment plants. Water Sci. Technol. 22. 319-320.

190. Volesky, B., 1990, "Biosorption and biosorbents", In: Biosorption of Heavy Metals, CRC Press, Boston.

191. Volesky, B., 1992. Removal of heavy metals by biosorption in harnessing biotechnology for the 21st century. (Eds) MR Ladisch and A Bose, American chemical society, Washington, DC.

192. Volesky, B., 1994. Advances in biosorption of metals: selection of biomass types. FEMS Microbiol. Rev. 14. 291302.

193. Yang, J., Wang, Qu., Wang, Q. and Wu, T., 2009. Heavy metals extraction from municipal solid waste incineration fly ash using adapted metal tolerant Aspergillus niger. Bioresour. Technol. 100(1), 254-260.

194. Yazdani, M., Chee, K.Y., Faridah, A., Soon, G.T., 2010. An in vitro study on the Adsorption, Absorption and uptake Capacity of $\mathrm{Zn}$ by the Bioremediator Trichoderma atroviride. Environ. Asia. 3. 53-59.

195. Yazdani, M., Yap, C.K., Abdullah, F. and Tan, S.G., 2010. An in vitro Study on the adsorption, absorption and uptake capacity of $\mathrm{Zn}$ by the bioremediator Trichoderma atroviride. Environ. Asia. 3. 53-59.

196. Yetis, U., Dolek, A., Dilek, F.B., Ozcengiz, G., 2000. The removal of $\mathrm{Pb}$ (II) by Phanerochaete chrysosporium. Water Res. 34. 4090-4100.

197. Zafar, S., Aqil, F. and Ahmad, I., 2007. Metal tolerance and biosorption potential of filamentous fungi isolated from metal contaminated agricultural soil, Biores. Technol., 98, 2557-2561.

198. Zeng, G.M., Huang, D. L., Huang, G. H., Hu, T. J., Jiang, X.Y., Feng, C. L., Chen, Y. N., Tang L., Liu, H.L., 2007. Composting of lead-contaminated solid waste with inoculums of white-rot fungus. Bioresour. Technol. 98. $320-$ 326.

199. Zorn, M.I., Van Gestel, C.A.M., Eijsackers, H., 2005. The effects of two endogenic earthworm species on zinc distribution and availability in artificial soil columns. Soil. Biochem. 37. 917-925.

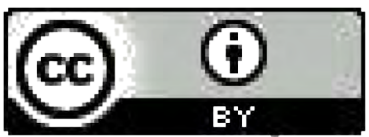

This work is licensed under a Creative Commons Attribution 4.0 International License. 